\title{
Artikkeli
}

\section{Ulkoinen vaikuttaminen ja sen vastakeinot suomalaisessa journalismissa}

\begin{abstract}
Journalismin autonomiaan ja journalisteihin kohdistuvat uhat ovat viime vuosina nousseet uudella tavalla näkyviksi Suomen julkisessa keskustelussa. Tutkimusta aiheesta on kuitenkin tehty vähän. Tämä artikkeli tarkastelee laadullisesti suomalaisten journalistien kokemuksia ulkoisesta vaikuttamisesta ja journalistien vaikuttamisen torjumiseen käyttämiä vastakeinoja. Ulkoiseksi vaikuttamiseksi määritellään kaikki sellaiset aktiiviset menetelmät, joilla ulkopuoliset toimijat pyrkivät puuttumaan journalismin autonomian alaan ja vaikuttamaan journalisteihin. Tutkimuksen aineisto koostuu journalistien teemahaastatteluista $(n=31)$ ja sidosryhmien kanssa tehdyistä taustahaastatteluista $(n=4)$. Sovelletun teema-analyysin perusteella journalistien kohtaamat ulkoisen vaikuttamisen menetelmät luokitellaan kuuteen ryhmään: 1) tiedonsaantiin kohdistuvat, 2) psykologiset, 3) fyysiset, 4) institutionaaliset, 5) taloudelliset ja 6) tietotekniset menetelmät. Tutkimushavaintojen perustella ulkoisen vaikuttamisen nykytilaa selittävät sekä journalismiin että yhteiskuntaan liittyvät kehityskulut, kuten toimitusten resurssien heikkeneminen, viestintätoiminnan lisääntyminen, tiedotusvälineiden ongelmat taloudellisten ansaintamallien löytämisessä ja yleisön suunnasta tulevien vaikutuspyrkimysten lisääntyminen. Tiedotusvälineiden kyvyllä vastata näihin haasteisiin voikin tulevaisuudessa olla merkittäviä seurauksia suomalaisen journalismin itsenäisyydelle ja autonomialle.
\end{abstract}

AVAINSANAT: Ulkoinen vaikuttaminen, uhkailu, häirintä, autonomia, professionalismi

ournalistinen autonomia voidaan määritellä journalistien pyrkimykseksi suojella omaa toimintaansa erilaisilta manipulointi- ja vaikutusyrityksiltä ja tehdä journalismia koskevat ratkaisut ammattikunnan sisäisesti määrittelemien periaatteiden mukaisesti (Kunelius 2003, 23; Waisbord 2013, 45-46). Yhteiskunnassa ja viestintäympäristössä tapahtuvat muutokset ja kehityskulut heijastuvat journalismin 
asemaan ja niihin olosuhteisiin, joissa journalismia tuotetaan (Waisbord 2013, 59-60; Pöyhtäri ym. 2016). Tämä näkyy myös journalistien kohtaamissa manipulaation ja vaikuttamisen menetelmissä, jotka muuttuvat ja kehittyvät jatkuvasti (Luostarinen 1994, 73). Journalismin autonomian tarkastelu edellyttää siis ajantasaista käsitystä siitä, millaisin keinoin ja menetelmin erilaiset toimijat pyrkivät tätä autonomiaa horjuttamaan.

Nykyisessä viestintäympäristössä perinteisen journalismin asema ja auktoriteetti ovat muutoksessa (Chadwick 2017) ja journalismi on pyrkinyt etsimään aikaisempaa vuorovaikutteisempaa ja läheisempää suhdetta yleisöönsä (esim. Pöyhtäri ym. 2016, 8; Reunanen \& Koljonen 2014, 115-117). Journalisteja on kannustettu tekemään työtään persoonallaan ja brändäämään itsensä työnsä kautta (Lehtonen 2013, 95). Erityisesti verkkoympäristössä journalistit ovat aikaisempaa näkyvämpiä ja helpommin yleisön tavoitettavissa, ja journalismin tuotokset ja työtavat ovat myös uudella tapaa julkisesti haastettavissa ja kyseenalaistettavissa (Löfgren Nilsson \& Örnebring 2016, 881; Manninen 2019, 266). Viestintäympäristön ja journalistisen kulttuurin muutoksen voidaan nähdä myös altistavan journalisteja uudentyyppisille vaikuttamiskeinoille, kuten joukkoistetulle häirinnälle (esim. Binns 2017), yleistyneelle vihapuheelle (esim. Obermaier ym. 2018; Pöyhtäri ym. 2013), verkkovainoamiselle (esim. Luque Martinez 2015) ja sukupuolittuneelle verkkohäirinnälle (esim. Chen ym. 2018; Adams 2018).

Yhteiskunnallisen ja poliittisen ilmapiirin on nähty kiristyneen ja mediavastaisen retoriikan yleistyneen Euroopassa (esim. RSF 2019). Journalismin autonomiaan ja journalisteihin kohdistuvat uhat ovat viime vuosina nousseet uudella tavalla näkyviksi myös Suomen julkisessa keskustelussa. Esimerkiksi Yleisradion toimittajan Jessikka Aron kohtaama poikkeuksellisen pitkään jatkunut häirintä-, mustamaalaus- ja uhkailukampanja on saanut kansainvälistä huomiota (Aro 2019). Turun Sanomien oikeustoimittajan Rebekka Härkösen kohtaama massiivinen vihapuhe- ja uhkailukampanja puolestaan nosti julkisuudessa esiin kysymyksen siitä, edellyttääkö erittäin tärkeä yleinen etu syytteiden nostamista silloin, kun vihapuheen ja uhan kohteena on työtään tekevä journalisti (Lehtilä 2018).

Ulkoisten toimijoiden pyrkimykset vaikuttaa journalististen organisaatioiden sisäiseen integriteettiin nousivat valtakunnalliseksi puheenaiheeksi myös joulukuussa 2016, kun Yleisradiossa työskennelleet journalistit syyttivät julkisesti silloista esihenkilöään, päätoimittaja Atte Jääskeläistä taipumisesta pääministeri Juha Sipilän painostukseen. Journalistien mukaan Jääskeläinen antoi ulkojournalististen syiden vaikuttaa Ylen journalismia koskevaan päätöksentekoon. (Koivunen 2017; Eronen ym. 2017.) Julkisen sanan neuvosto antoi asiassa harvinaisen langettavan päätöksen, jossa katsoi Ylen luovuttaneen journalistista päätösvaltaansa toimituksen ulkopuolelle (JSN 2017). Tapauksen jälkeen Ylen journalistisesta päätöksenteosta laadittu riippumaton selvitys piti ongelmallisena, että poliittisten ja yhteiskunnallisten vallankäyttäjien suorat pyrkimykset vaikuttaa journalistiseen sisältöön ovat vakiintuneet yleisiksi toimintatavoiksi Suomessa (Mäenpää 2017, 21-22).

Tämä artikkeli tarkastelee empiirisesti suomalaisten journalistien kokemuksia ulkoisesta vaikuttamisesta ja journalistien ulkoisen vaikuttamisen torjumiseen käyttämiä vastakeinoja. Päämääränä on tuottaa laadulliseen haastatteluaineistoon perus- 
tuva luokittelu ulkoisen vaikuttamisen menetelmistä ja niiden vastakeinoista nykyisessä viestintäympäristössä. Luokittelun avulla on mahdollista jäsentää yhteiskunnassamme tällä hetkellä journalismin autonomiaa uhkaavia tekijöitä ja sitä, millaisiin laajempiin trendeihin nämä uhat kytkeytyvät. Artikkelin tutkimuskysymykset ovat:

1 Millaisia ulkoisen vaikuttamisen menetelmiä suomalaiset journalistit kohtaavat työssään?

2) Millaisia vastakeinoja suomalaiset journalistit käyttävät ulkoisen vaikuttamisen torjumiseen?

Tämä artikkeli on osa laajempaa monimenetelmällistä väitöstutkimusta, joka keskittyy journalistien kohtaamaan ulkoiseen vaikuttamiseen Suomessa. Artikkeli tarkastelee laadullisesti vaikutusyritysten ja vastakeinojen sisältöä täydentäen näin aikaisempia tutkimusjulkaisuja, joissa selvitettiin määrällisin menetelmin ulkoisen vaikuttamisen kokemusten yleisyyttä ja jakautumista koko suomalaisen journalistikunnan tasolla (Hiltunen 2019; Hiltunen \& Suuronen 2020; Hiltunen \& Suuronen 2019a).

Luon ensin katsauksen aihetta käsittelevään tutkimukseen ja määrittelen ulkoisen vaikuttamisen käsitteen. Tämän jälkeen esittelen tutkimusaineiston ja analyysimenetelmän. Tuloksissa erittelen journalistien kohtaamat ulkoisen vaikuttamisen menetelmät ja journalistien niiden torjumiseen käyttämät vastakeinot kuuteen luokkaan. Esitän nämä jokaisen luokan osalta myös taulukkomuodossa. Lopuksi pohdin analyysituloksiin ja aikaisempaan tutkimukseen nojautuen laajemmin sitä, millaisia viestintäympäristön ja yhteiskunnan muutoksia ulkoisen vaikuttamisen nykytilan taustalla voidaan hahmottaa.

\section{Aikaisempi tutkimus ja ulkoisen vaikuttamisen käsite}

Journalismi on yhteiskunnallisesti keskeinen tiedon tuottaja, ja journalistinen julkisuus toimii intressijulkisuutena, jossa erilaiset diskurssit ja edunajajat kokoontuvat ja kilvoittelevat (Luostarinen 1994, 28-29). Journalismiin vaikuttaminen takaa toimijoille etuja, joita ne eivät välttämättä saavuttaisi muilla julkisuuden hallinnan menetelmillä (emt., 53). Yleisö suhtautuu mainontaan ja tiedotusmateriaaliin lähtökohtaisesti eri tavalla kuin journalismiin, jolta odotetaan itsenäisyyttä ja yleisen edun edustamista (Mäntylä 2008, 130-131; Kunelius 2003, 23-25). Mikäli vaikuttamaan pyrkivän tahon viestin välittäjäksi saadaan puolueettomana ja itsenäisenä pidetty journalismi, viestin uskottavuus ja sen myötä vaikuttavuus kasvavat merkittävästi (Luostarinen 1994, 16, 39-41; Kunelius 2003, 23-25). Journalismi voi toiminnallaan myös tuottaa erilaisille toimijoille negatiivista julkisuutta ja mainehaittoja nostamalla esille niiden kannalta kielteisiä seikkoja sekä kiinnittämällä yleisön huomiota niihin. Ulkopuolisilla toimijoilla on siis useita syitä pyrkiä puuttumaan journalistien työhön ja journalismin sisältöön. 
Aikaisempi tutkimus ulkopuolisten toimijoiden puuttumisesta journalistien työhön ja journalismiin on yleensä tarkastellut ilmiötä epävakaissa tai autoritaarisissa ja puoliautoritaarisissa yhteiskunnissa ja painottunut äärimmäisiin menetelmiin, kuten väkivaltaan ja journalistien vangitsemisiin (Clark \& Grech 2017, 22; Löfgren Nilsson \& Örnebring 2016, 880-881; Parker 2015, 2-3). Kirjallisuuskatsauksensa perusteella Urbániková $(2019,4-5)$ toteaa, että vakaissa ja demokraattisissa länsimaissa on tyypillisesti tyydytty tarkastelemaan journalistien yleisiä näkemyksiä työnsä vapaudesta ja autonomiasta, eikä erilaisia ulkoisen vaikuttamisen ja kontrollin menetelmiä, tyyppejä ja seurauksia ole tutkimuksissa usein konkretisoitu tai mitattu. Empiiriset tutkimukset vaikuttamisen menetelmistä ovat yleensä keskittyneet vain rajattuihin osa-alueisiin, esimerkiksi journalistien kohtaamaan verkkovihaan (emt.) ja useampia ulkoisen vaikuttamisen menetelmiä samanaikaisesti tarkastelevat tutkimukset (ks. esim. Clark \& Grech 2017; Parker 2015; Kodellas ym. 2014) ovat harvinaisia. Tämä artikkeli paikkaa aukkoa aikaisemmassa tutkimustiedossa esittelemällä empiriaan perustuvan luokittelun konkreettisista ulkoisen vaikuttamisen menetelmistä Suomessa, joka lukeutuu korkean sananvapauden länsimaisten demokratioiden joukkoon.

Kirjallisuuskatsaukseen perustuvassa luokitellussaan Luostarinen (1994) jakaa journalismiin kohdistuvat vaikuttamisen menetelmät niiden pääasiallisen tavoitteen mukaan painostaviin, rajoittaviin ja suostutteleviin menetelmiin. Painostavat menetelmät kattavat fyysisen, taloudellisen, poliittisen ja ammatillisen painostuksen, jossa tarkoitus on suoraan tai erilaisten sanktioiden välityksellä vaikuttaa journalismin sisältöön. Rajoittaviin menetelmiin sisältyvät informaation saantia ja käyttöä sekä journalismin editointivaltaa kaventavat toimenpiteet, kuten tiukkojen reunaehtojen asettaminen tietojen tai haastattelujen saamiselle. Suostuttelevat menetelmät sisältävät erilaisten henkilökohtaisten suhteiden käyttämisen vaikuttamiseen sekä taloudellisten etujen tarjoamisen ja lahjonnan muodot.

Goyanes ja Rodríguez-Castro (2018) erottavat sisäisen ja ulkoisen painostuksen lisäksi painostuksen kohdentamisen (suora vai epäsuora), ajallisuuden suhteessa journalistiseen prosessiin (ennen julkaisua vai sen jälkeen) ja journalistien tulkinnat painostuksen tavoitteista. Suorassa painostuksessa toimijat ovat suoraan yhteydessä jutusta vastaavaan journalistiin. Epäsuorassa painostuksessa ulkopuolinen toimija on yhteydessä esihenkilöihin tai välineen omistajiin, ja painostus välittyy journalistille journalistisen komentoketjun välityksellä. Ajallisesti painetta voidaan kohdistaa journalistiseen prosessiin ennen jutun julkaisua (a priori) tavoitteena julkaisemisen estäminen, viivästyttäminen tai jutun sisältöön vaikuttaminen. Julkaisun jälkeisen (post hoc) paineen tavoitteena on esimerkiksi tuoda toimijan mielipide journalistin ja välineen tietoon, esittää kritiikkiä, kyseenalaistaa jutun sisältöä ja luotettavuutta, vaatia perusteita siinä tehdyille ratkaisuille tai pyrkiä vaikuttamaan aiheen mahdolliseen jatkokäsittelyyn.

Suomalaisen journalismin kontekstissa ajantasaista tutkimusta ulkoisesta vaikuttamisesta on tehty erittäin vähän, eikä vaikuttamisen menetelmiä ole aikaisemmin juuri tarkasteltu laadullisesti. Yleisesti suomalaiset journalistit ovat kokeneet olevansa itsenäisiä erityisesti suhteessa erilaisiin ulkopuolisiin toimijoihin (Pöyhtäri ym. 2014, 
26). Pohjoismaiset journalistit kokevat vähäisempää taloudellisten paineiden vaikutusta työhönsä muihin korkean sanavapauden maihin verrattuna, joskin suomalaiset ja tanskalaiset toimittajat raportoivat enemmän poliittista painetta kuin journalistit muissa Pohjoismaissa (Ahva ym. 2017, 607). Lisäksi esimerkiksi vihapuheen koetun yleistymisen on havaittu vaikuttavan suomalaiseen journalismiin henkisen kuormituksen ja itsesensuurin kautta (Pöyhtäri ym. 2013, 134-137).

Määrittelen tässä tutkimuksessa ulkoisen vaikuttamisen laajasti sellaisten aktiivisten, journalismin autonomian alaan vaikuttamaan pyrkivien menetelmien käyttämiseksi, joilla toimitusorganisaation ulkopuolinen taho pyrkii vaikuttamaan journalistiseen prosessiin ja/tai journalisteihin ja tätä kautta journalismin sisältöön (vrt. Clark \& Grech 2017; Luostarinen 1994). Ulkoinen vaikuttaminen toimii siis tutkimuksen kattokäsitteenä, jonka alla voidaan tarkastella vaikuttamisen menetelmien kokonaiskirjoa ulottuen journalistisiin prosesseihin puuttumisesta aina aggressiiviseen ja suoraviivaiseen painostukseen asti. Näin voidaan myös tavoittaa menetelmien yhteisvaikutusta, sillä erityyppisiä vaikuttamisen menetelmiä kohdistetaan journalisteihin usein samanaikaisesti.

Tällä tavoin määriteltynä ulkoinen vaikuttaminen kattaa myös useita sellaisia toimintatapoja, jotka journalistista työtä käsittelevissä tutkimuksissa on yleensä niputettu käsitteen häirintä (engl. harassment) alle (vrt. esim. Pöyhtäri ym. 2013; Löfgren Nilsson \& Örnebring 2016; Miller \& Lewis 2020). Yhdenvertaisuuslain (Finlex 2020) määritelmään nojautuen määrittelen häirinnän sellaisiksi pyrkimyksiksi luoda henkilöä halventava tai nöyryyttävä taikka häntä kohtaan uhkaava, vihamielinen tai hyökkäävä ilmapiiri, jotka kohdistetaan journalistiin nimenomaan hänen työnsä vuoksi. Käytän siis häirintää tässä artikkelissa yleiskäsitteenä kuvaamaan niitä ulkoisen vaikuttamisen menetelmiä ja menetelmien yhdistelmiä, joiden pyrkimyksenä on vaikuttaa journalistin työhön tuottamalla edellä kuvatun kaltaisia negatiivisia psykologisia seurauksia. Kaiken häirinnän taustalla ei kuitenkaan automaattisesti ole välineellistä pyrkimystä vaikuttaa journalistin tekemään työhön. Esimerkiksi seksuaalinen häirintä ei näin ollen kuulu tämän tutkimuksen alaan, ellei uhri nimenomaisesti koe sen tavoitteena olevan hänen journalistiseen työhönsä vaikuttaminen. (vrt. Miller \& Lewis 2020, 3-4.)

Lasken tutkimuksen alaan myös yhdistelmävaikuttamisen sellaisissa tapauksissa, joihin selkeästi kytkeytyy ulkoisia toimijoita tai elementtejä. Yhdistelmävaikuttamisessa ulkoinen vaikuttaminen ja toimituksellisen organisaation sisällä tapahtuva sisäinen vaikuttaminen esiintyvät toisiinsa limittyneinä. Tyypillinen esimerkki on ulkoisen vaikuttamisen eteneminen journalistisessa komentoketjussa tiedotusvälineen sisällä: Päätoimittaja päättää ulkoisen painostuksen seurauksena välittää sisäisen käskyn journalistisen prosessin keskeyttämisestä alaisilleen. (Hemánus 1983, 192; ks. myös Kuutti 1995, 248.)

Soveltamani ulkoisen vaikuttamisen määritelmän ulkopuolelle jää perinteinen viestintävaikuttaminen, kuten mediatiedotteet, infopaketit, järjestetyt mediatapahtumat sekä muut vastaavat pyrkimykset median huomion kiinnittämiseen ja agendan ohjaamiseen. Journalisteihin kohdistuvan markkinointi- ja vaikuttajaviestinnän sekä 
lobbauksen menetelmistä nykyisessä viestintäympäristössä löytyy ajantasaista tutkimusta niin Suomesta (Mykkänen ym. 2020) kuin muista demokraattisista länsimaista (ks. Mykkänen \& Ikonen 2019). Vaikka tällaisilla menetelmillä voidaan osoittaa olevan seurauksia journalismin sisällölle (esim. Juntunen 2011), ne eivät pyri aktiivisesti puuttumaan journalismin autonomiaan. Päätösvalta esimerkiksi tiedotemateriaalin käyttämisestä, mediatapahtumasta raportoinnista tai juttuvinkkiin tarttumisesta on aina journalistisella organisaatiolla itsellään (ks. myös Luostarinen 1994, 15), eivätkä tällaiset viestintävaikuttamisen keinot siis kuulu tämän tutkimuksen alaan.

\section{Aineisto ja menetelmä}

\section{Tutkimusaineisto}

Tutkimusaineistoni koostuu suomalaisten journalistien puolistrukturoiduista teemahaastatteluista $(n=31)$ ja aihepiirin kanssa tekemisissä olevien sidosryhmien kanssa tehdyistä taustahaastatteluista $(n=4)$. Sidosryhmähaastattelut tein Julkisen sanan neuvoston, Suomen Journalistiliiton ja Päätoimittajien Yhdistyksen puheenjohtajien sekä Yleisradion journalististen standardien ja etiikan päällikön kanssa. Kaikki tutkimuksen haastattelut tehtiin yksilöhaastatteluina vuoden 2018 tammikuun ja vuoden 2019 joulukuun välisenä aikana. Haastattelut nauhoitettiin ja litteroitiin sanatarkasti.

Koostin teemahaastattelujen otoksen kriittisten tapausten otannalla $(n=15)$, jota täydensin suurimman vaihtelun otannalla $(n=16)$ (Patton 1990, 172-175). Kriittisten tapausten otantaan (critical case sampling) valikoin näkyviä suomalaisia journalisteja, jotka työskentelevät ulkoiselle vaikuttamiselle alttiiden aihepiirien, kuten talouden, politiikan, ulkomaanaiheiden, rikos- ja oikeusaiheiden sekä tutkivan journalismin parissa (ks. Hiltunen \& Suuronen 2019b, 109-114; Parker 2015, 96). Suurimman vaihtelun otannan (maximum variety sampling) haastateltavat poimin aikaisemman aihetta käsittelevän kyselytutkimuksen (Hiltunen 2019) vastaajien joukosta. Nämä vastaajat olivat kyselyssä ilmaisseet halukkuutensa osallistua tutkimushaastatteluun. Valintaperusteena käytin pyrkimystä maksimoida tutkimusotoksen demografinen ja ammatillinen monimuotoisuus. Kahden otantamenetelmän yhdistelmällä pyrin tavoittamaan aineistoon mahdollisimman monipuolisen kokemusten kirjon (Patton 1990) ja edistämään näin tutkimuksen pyrkimystä tuottaa laaja analyyttinen luokittelu erilaisista ulkoisen vaikuttamisen ilmenemismuodoista.

Sidosryhmähaastattelut toteutin tutkimuksen loppuvaiheessa, ja niissä käsiteltiin aikaisemmissa tutkimushaastatteluissa esiin nousseita teemoja. Analyysivaiheessa hyödynsin sidosryhmähaastatteluja tausta-aineistona tutkimushavaintojen laajempaan kontekstointiin.

Otin haastateltaviin yhteyttä henkilökohtaisesti sähköpostilla tai puhelimitse. Tutkimuksen teemahaastatteluista 24 tehtiin Skypen tai vastaavan etävideoyhteyden välityksellä ja 7 kasvokkain. Kiireisten ammattijournalistien haastattelemisessa etäyhteyden käyttäminen tarjosi lukuisia etuja. Haastatteluajankohta voitiin sopia joustavasti haastateltavan ehdoilla eikä järjestelyissä tarvinnut huomioida maantieteel- 
lisiä etäisyyksiä. Vuorovaikutustilanteen näkökulmasta etäyhteyden käyttämistä on pidetty erityisen sopivana henkilökohtaisten ja arkaluontoisten aiheiden käsittelyyn, sillä haastateltava voi itse valita mieleisen ja turvalliseksi kokemansa haastatteluympäristön ja tilanteesta on helpompi ottaa etäisyyttä kuin kasvokkain toteutetusta tutkimushaastattelusta (ks. Oates 2015). Varjopuolena etäyhteyden käytössä olivat ajoittaiset yhteysongelmat, jotka toisinaan haittaisivat kommunikointia tai keskeyttivät hetkeksi haastattelun.

Teemahaastattelujen kesto vaihteli 43 minuutista 121 minuuttiin keskipituuden ollessa 73 minuuttia. Haastateltavilla oli mahdollisuus täydentää haastattelujaan myöhemmin. Yksi journalisteista kieltäytyi osallistumasta tutkimukseen henkilökohtaisista syistä.

Haastateltujen journalistien joukko oli heterogeeninen ja sisälsi taustoiltaan, työtehtäviltään, kokemukseltaan ja erikoistumisalaltaan hyvin erilaisia journalisteja. Tutkimusotoksen keskeiset taustatiedot on koottu taulukkoon 1.

Taulukko 1. Tutkimusotoksen taustatiedot $(n=31)$.

\begin{tabular}{|lr|lr|ll|}
\hline Sukupuoli & $\mathbf{n}$ & Koulutus & $\mathbf{n}$ & Työtehtävä & $\mathbf{n}$ \\
\hline Nainen & 18 & $\begin{array}{l}\text { Maisterintutkinto tai } \\
\text { korkeampi akateeminen tutkinto }\end{array}$ & 14 & Päätoimittaja & 3 \\
\hline Mies & 13 & Kandidaatintutkinto & 3 & Päällikkötoimittaja & 4 \\
\hline & Ammattikorkeakoulututkinto & 4 & Tuottaja & 1 \\
\hline & $\begin{array}{l}\text { Yliopisto-opintoja ilman } \\
\text { loppututkintoa }\end{array}$ & 4 & Erikoistoimittaja & 9 \\
\hline & Ylioppilastutkinto & 4 & Toimittaja & 14 \\
\hline & Ammatillinen koulutus & 2 & & \\
\hline
\end{tabular}

Haastateltujen journalistien ikähaarukka ulottui 27 vuodesta 65 vuoteen keski-iän ollessa 44 vuotta. Heidän työkokemuksensa vaihteli 8 vuodesta 42 vuoteen, ja keskimääräinen työkokemus alalla oli 21 vuotta. Haastatelluista journalisteista 22 työskenteli vakituisessa työsuhteessa tiedotusvälineessä ja 7 freelancereina. Yhdellä haastatelluista oli yhdistelmä erilaisia työsuhteita, ja yksi oli hiljattain vaihtanut alaa. Vakituisessa työsuhteessa olevien journalistien tiedotusvälineet on koottu taulukkoon 2. 
Taulukko 2. Tutkimusotoksen vakituisessa työsuhteessa työskentelevien journalistien tiedotusvälineet $(n=22)$.

\begin{tabular}{|l|r|}
\hline Tiedotusväline & $\mathbf{n}$ \\
\hline Valtakunnallinen sanomalehti & 3 \\
\hline Yleisradio & 3 \\
\hline Iltapäivälehti & 3 \\
\hline Aluelehti & 3 \\
\hline Paikallislehti tai kaupunkilehti & 3 \\
\hline Aikakauslehti & 3 \\
\hline Maakuntalehti & 2 \\
\hline Kaupallinen televisiokanava & 1 \\
\hline Uutistoimisto & 1 \\
\hline
\end{tabular}

\section{Teemahaastattelurunko}

Tutkimuksen teemahaastattelurunko (ks. liite 1 ) koostui kolmesta temaattisesta osasta: 1) kokemukset ulkoisesta vaikuttamisesta, 2) ulkoisen vaikuttamisen käsittely työssä ja työyhteisössä ja 3) näkemykset ulkoisesta vaikuttamisesta. Teemahaastattelujen puolistrukturoitu rakenne mahdollisti sen, että jokaisen haastateltavan kanssa voitiin keskittyä juuri tämän oman työn näkökulmasta keskeisiin ulkoisen vaikuttamisen kokemuksiin (Hirsjärvi \& Hurme 1995). Näin tuotetusta haastatteluaineistosta muodostui monipuolinen ja moniääninen. Koska ulkoiseen vaikuttamiseen liittyviä henkilökohtaisia kokemuksia ja vaikuttamisen seurauksia journalistiselle työlle voidaan pitää sensitiivisenä aihepiirinä, tutkimushaastattelut tehtiin anonyymisti ja niitä käsitellään tässä tutkimuksessa myös epäsuoria tunnisteita välttäen.

\section{Aineiston analyysi}

Käsittelin aineistoa samanaikaisesti sekä faktuaalisena tiedonlähteenä journalisteille tapahtuneista asioista että toimittajien itsereflektiona kuvaamassa kokemuksia sekä niihin liittyviä ajatuksia ja tunteita (Bernard \& Ryan 1998). Aineiston analyysimenetelmänä käytin aineistolähtöistä sovellettua teema-analyysia (Guest ym. 2012). Koodasin teemahaastatteluaineiston tietokoneavusteisesti kahteen kertaan Atlas.ti 8 -analyysiohjelmalla. Ensimmäisellä kerralla käytin aihekoodausta (Saldaña 2013, 87-91) erilaisten ulkoisen vaikuttamisen kokemusten, menetelmien ja journalistien käyttämien vastakeinojen merkitsemiseen. Toisella koodauskerralla yhdistin aihekoodatut vaikuttamisen menetelmät ja vastakeinot laajemmiksi temaattisiksi kokonaisuuksiksi (emt., 209-213). 
Luokitteluprosessissa määrittelin merkitseviksi tekijöiksi (Kluge 2000) journalistien näkemykset vaikuttamisen menetelmän pääasiallisesta vaikutustavasta ja vaikuttamisen kanavasta (vrt. Luostarinen 1994; Goyanes \& Rodríguez-Castro 2018; Clark \& Grech 2017). Näiden tekijöiden perusteella jaoin aineistossa esiintyneet vaikuttamisen menetelmät kuuteen luokkaan. Liitin jokaisen vaikuttamisen menetelmän vastinpariksi ne journalistien käyttämät vastakeinot, jotka haastatteluaineistossa eksplisiittisesti yhdistettiin kyseiseen menetelmään.

\section{Tulokset}

Luokittelin analyysissäni ulkoisen vaikuttamisen menetelmät kuuteen luokkaan: 1) tiedonhankintaan kohdistuvat, 2) psykologiset, 3) fyysiset, 4) institutionaaliset, 5) taloudelliset ja 6) tietotekniset menetelmät.

Erilaiset vaikuttamisen menetelmät esiintyvät usein samanaikaisesti ja toisiinsa limittyneinä, ja niiden selkeä erottaminen voi käytännössä olla hyvin hankalaa. Lisäksi raja epäeettisen vaikuttamisen ja hyväksyttävän toiminnan välillä voi olla journalistien näkökulmasta häilyvä, ja toiset journalisteista saattavat suhtautua toimintaan torjuvammin kuin toiset (ks. myös Pöyhtäri ym. 2016, 17). Näin ollen tässä artikkelissa esitettyä luokittelua ei ole syytä ymmärtää selvärajaiseksi ja kaikenkattavaksi, vaan analyyttiseksi apuvälineeksi ulkoisen vaikuttamisen menetelmien kirjon hahmottamiseen. Luokittelu on myös syytä käsittää dynaamisena ja täydentyvänä, sillä ulkoisen vaikuttamisen menetelmät ja sen vastakeinot ovat jatkuvasti muutoksessa (Luostarinen 1994, 73).

Ulkoinen vaikuttaminen kohdistuu journalismiin tyypillisesti lähteiden, kohteiden tai yleisön taholta. Nykyisessä viestintäympäristössä verkon alustat ovat lisänneet yksilöiden mahdollisuuksia muodostaa löyhiä yhteenliittymiä ja toimia koordinoidusti yhdessä. Nämä samanmielisten verkostot muodostavat tyypillisesti omia intressijulkisuuksiansa ja pyrkivät usein vaikuttamaan niille keskeisten asioiden käsittelyyn myös journalistisessa julkisuudessa. (vrt. Rinne 2011.) Tällaisen toiminnan lisääntyminen nousi usein esille haastatteluissa.

Vaikutuspyrkimysten motiivit ovat moninaisia ja voivat vaihdella taloudellisten intressien suojelemisesta aina henkilökohtaisten poliittisten ja ideologisten näkemysten edistämiseen. On syytä huomioida, että erilaisilla toimijoilla on käytössään vaihtelevia resursseja ja mahdollisuuksia ulkoisen vaikuttamisen menetelmien käyttöön, ja että myös journalistien käyttämillä vastakeinoilla voi olla erilaisia seurauksia näille toimijoille. Esimerkiksi poliitikko voi siis pyrkiä käyttämään vaikuttamisessa hyväkseen yhteiskunnallista valta-asemaansa eri tavalla kuin tavallinen kansalainen, mutta vaikutuspyrkimysten tuominen julki todennäköisesti vahingoittaa poliitikon julkikuvaa ja tämän intressejä eri tavalla kuin kansalaisella. (ks. Kunelius ym. 2010; Luostarinen 1994.) 


\section{1) Tiedonhankintaan kohdistuvat menetelmät}

Tiedonhankintaan kohdistuvaksi ulkoiseksi vaikuttamiseksi luokittelen kaikki sellaiset menetelmät, joissa pyritään aktiivisesti puuttumaan journalistien tiedonhankintaan ja työprosesseihin. Määrittelen kategoriaan kuuluviksi pyrkimykset tiedonsaannin ja haastattelujen kontrollointiin, julkisten tietojen saannin tahallisen vaikeuttamisen tai estämisen sekä juttujen ennakkotarkastukseen liittyvän vaikuttamisen. Nämä on kuvattu taulukossa 3.

Taulukko 3. Tiedonhankintaan kohdistuvat ulkoisen vaikuttamisen menetelmät.

\begin{tabular}{|c|c|c|c|}
\hline $\begin{array}{l}\text { Vaikuttamisen } \\
\text { menetelmä }\end{array}$ & $\begin{array}{l}\text { Tyypilliset } \\
\text { toteutustavat }\end{array}$ & $\begin{array}{l}\text { Vaikuttamisen } \\
\text { tavoitteet }\end{array}$ & $\begin{array}{l}\text { Journalistin } \\
\text { vastakeinot }\end{array}$ \\
\hline $\begin{array}{l}\text { Tiedonsaannin ja } \\
\text { haastattelujen } \\
\text { kontrollointi }\end{array}$ & $\begin{array}{l}\text { - Erilaisten ennakko- } \\
\text { ehtojen asettami- } \\
\text { nen haastatteluille } \\
\text { ja muulle tiedon- } \\
\text { hankinnalle. } \\
\text { - Viestintäammatti- } \\
\text { laisten läsnäolo yli- } \\
\text { määräisinä henki- } \\
\text { löinä haastattelu- } \\
\text { tilanteissa. }\end{array}$ & $\begin{array}{l}\text { - Vaikuttaa aiheisiin, } \\
\text { joiden yhteydessä } \\
\text { toimija on journalis- } \\
\text { missa esillä. } \\
\text { - Kontrolloida ulos- } \\
\text { päin annettavaa } \\
\text { tietoa. } \\
\text { - Valvoa haastelta- } \\
\text { vien sanomisia ja } \\
\text { muuttaa haastatte- } \\
\text { lutilanteiden dyna- } \\
\text { miikkaa. } \\
\text { - Varautua juttujen } \\
\text { seurauksiin ja estää } \\
\text { ennalta negatiivista } \\
\text { julkisuutta. }\end{array}$ & $\begin{array}{l}\text { - Kieltäytyminen } \\
\text { haastatteluille } \\
\text { tai tiedonhankin- } \\
\text { nalle asetetuista } \\
\text { ehdoista. } \\
\text { - Ylimääräisten hen- } \\
\text { kilöiden poistami- } \\
\text { nen haastattelu- } \\
\text { tilanteista. } \\
\text { • Jutun tekeminen } \\
\text { ilman kohteen } \\
\text { yhteistyötä esim. } \\
\text { julkisiin lähteisiin, } \\
\text { asiakirjoihin ja vuo- } \\
\text { toihin perustuen. }\end{array}$ \\
\hline $\begin{array}{l}\text { Julkisten tietojen } \\
\text { saamisen tahallinen } \\
\text { vaikeuttaminen tai } \\
\text { estäminen }\end{array}$ & $\begin{array}{l}\text { - Kieltäytyminen jul- } \\
\text { kisten tietojen luo- } \\
\text { vuttamisesta tai } \\
\text { tietojen perustee- } \\
\text { ton leimaaminen } \\
\text { salassa pidettä- } \\
\text { väksi. } \\
\text { - Huomattavan kor- } \\
\text { keiden maksujen } \\
\text { periminen aineis- } \\
\text { tosta. }\end{array}$ & $\begin{array}{l}\text { - Tietojen julkisen } \\
\text { käsittelyn estä- } \\
\text { minen. } \\
\text { - Tietojen julkaisun } \\
\text { viivyttäminen. }\end{array}$ & $\begin{array}{l}\text { - Julkisuuslain tun- } \\
\text { teminen ja siihen } \\
\text { vetoaminen. } \\
\text { - Valmius valittaa } \\
\text { päätöksistä oikeus- } \\
\text { teitse. } \\
\text { - Tietojen hankkimi- } \\
\text { nen vaihtoehtoisista } \\
\text { kanavista esim. } \\
\text { vuotoina. }\end{array}$ \\
\hline $\begin{array}{l}\text { Vaatimukset } \\
\text { ennakkotarkastus- } \\
\text { tilanteessa }\end{array}$ & $\begin{array}{l}\text { - Journalistisesti } \\
\text { perusteeton puut- } \\
\text { tuminen jutun sisäl- } \\
\text { töön ennakko- } \\
\text { tarkastustilanteessa } \\
\text { ennen jutun julkai- } \\
\text { sua. }\end{array}$ & $\begin{array}{l}\text { - Muuttaa tai poistaa } \\
\text { toimijan näkökul- } \\
\text { masta negatiivista } \\
\text { sisältöä ennen jul- } \\
\text { kaisua. }\end{array}$ & $\begin{array}{l}\text { - Haastattelujen } \\
\text { ja muun viestin- } \\
\text { vaihdon tekninen } \\
\text { tallentaminen ja } \\
\text { säilyttäminen. }\end{array}$ \\
\hline
\end{tabular}


Tiedonsaannin ja haastattelujen kontrollointia voidaan pitää hankalasti rajattavana ja määriteltävänä. Tässä yhteydessä viittaan sillä toimintaan, jossa pyritään aktiivisesti puuttumaan haastatteluihin ja tiedonhankintaan liittyviin journalistisiin prosesseihin. Käytännössä nämä saattoivat olla esimerkiksi haastattelutilanteille ja haastattelujen toteutukselle ennalta asetettuja ehtoja ja rajoituksia, kuten vaatimuksia kysymysten näkemisestä etukäteen tai niihin vastaamista vain kirjallisesti ja valikoiden. Lisäksi haastattelun ehdoksi voitiin pyrkiä asettamaan viestintäammattilaisen läsnäolo ylimääräisenä henkilönä haastattelutilanteessa. Tällaista vaikuttamista vastaan journalistit käyttivät reaktiivisia vastakeinoja, kuten vaatimusten ja rajoitusten torjumista ja ylimääräisten henkilöiden poistamista haastattelutilanteista. Tiedonhankintaan kohdistuvan vaikuttamisen määrittelemisessä syntyi myös hajontaa journalistikunnan sisällä. Kaikki haastatellut eivät esimerkiksi pitäneet viestintähenkilöiden läsnäoloa haastatteluissa varsinaisena ulkoisen vaikuttamisen menetelmänä.

Julkisten tietojen saamisen tahallinen vaikeuttaminen tai estäminen kattaa pyrkimykset olla luovuttamatta julkisia asiakirjoja, viivyttää niiden luovuttamista tai estää niiden käsittely perimällä aineistosta huomattavan korkeita maksuja. Näin toimittiin journalistien mukaan usein silloin, kun käsiteltävä asia oli esimerkiksi viranomaisen, kaupungin tai kunnan näkökulmasta kiusallinen tai negatiivinen. Mikäli asiakirjoja jouduttiin vastakeinona hakemaan hallinto-oikeuden kautta, usein vuosia kestävä valitusprosessi esti tietojen ajankohtaisen käsittelyn journalismissa. Alla oleva lainaus kuvaa tiedonsaantiin liittyviä ongelmia:

\section{[...] se on iso ongelma koska sitte, pahimmillaan käy niin että mä joudun kolme vuotta} odottamaan että mä saan korkeimmasta hallinto-oikeudesta lopulta sitte, ratkasun. Et mä saan jotku asiakirjat. Sillon saattaa olla että se juttu on vanhentunu siinä välissä. [...] se hankaloittaa kyl duunii suunnattomasti, semmonen julkisuuslain noudattamatta jättäminen tavallaan. Tai et tulkitaan, tavallaan julkisuuslain hengen vastasesti että, tyydytään salata ennemminki ku pitää julkisena asiakirjoja. ( $\left.\mathrm{H}_{5}\right)$

Julkisuuslain rikkominen tietoja salaamalla ei journalistien mukaan käytännössä johda sanktioihin. Tästä syystä journalistit kokivat, ettei viranomaisilla ja virkamiehillä usein ole todellista painetta noudattaa julkisuuslakia. Asiakirjoja saatettiin salata jopa "varmuuden vuoksi" silloin, kun viranomaiset tai virkamiehet halusivat turvata selustansa päätöksen seurauksilta (ks. myös Kuutti 2011).

Ennakkotarkastukseen liittyväksi ulkoiseksi vaikuttamiseksi määrittelen tilanteet, joissa jutuissa siteeratut henkilöt pyrkivät saamaan läpi journalistisesti perusteettomia muutoksia tai poistoja ennakkotarkastusvaiheessa ennen jutun julkaisua. Ennakkotarkastukseen liittyvissä ristiriitatilanteissa journalistit hyötyivät usein siitä, että lainaukset voitiin todentaa oikeiksi jälkikäteen esimerkiksi haastattelunauhojen avulla. Haastatellun oikeus sitaattien tarkastamiseen on kirjattu Journalistin ohjeisiin, mutta tarkastamisen yhteydessä ei saa luovuttaa journalistista päätösvaltaa toimituksen ulkopuolelle (JSN 2020). Journalistien mukaan haastateltavat saattoivat kuitenkin kierrättää ennakkotarkastettavaksi lähetetyt sitaatit tai jutut myös viestintäammatti- 
laisilla, jotka sitten pyrkivät hanakasti saamaan läpi omia vaatimuksiaan. Käytäntönä ennakkotarkastuksella nähtiin myös positiivisia seurauksia: Se mahdollisti esimerkiksi virheiden ja väärinkäsitysten korjaamisen jutusta jo ennen julkaisua (ks. Hiltunen 2019, 10-11).

\section{2) Psykologiset menetelmät}

Psykologiseksi ulkoiseksi vaikuttamiseksi määrittelen menetelmät, jotka pyrkivät vaikuttamaan pääasiassa psykologisen paineen välityksellä (ks. Clark \& Grech 2017). Näihin menetelmiin sisältyy usein myös laajempi pyrkimys vaikuttaa negatiivisten psykologisten seurausten kautta journalistien haluun käsitellä tiettyjä aiheita tai näkökulmia (emt., 6o; Löfgren Nilsson \& Örnebring 2016). Psykologiset vaikuttamisen menetelmät on kuvattu taulukossa 4.

Taulukko 4. Psykologiset ulkoisen vaikuttamisen menetelmät.

\begin{tabular}{|c|c|c|c|}
\hline $\begin{array}{l}\text { Vaikuttamisen } \\
\text { menetelmä }\end{array}$ & $\begin{array}{l}\text { Tyypilliset } \\
\text { toteutustavat }\end{array}$ & $\begin{array}{l}\text { Vaikuttamisen } \\
\text { tavoitteet }\end{array}$ & $\begin{array}{l}\text { Journalistin } \\
\text { vastakeinot }\end{array}$ \\
\hline $\begin{array}{l}\text { Perusteettomat } \\
\text { oikaisu- tai } \\
\text { vastinevaatimukset }\end{array}$ & $\begin{array}{l}\text { - Vaatimusten lähet- } \\
\text { täminen journalis- } \\
\text { tille tai esihenkilölle } \\
\text { jutun julkaisun jäl- } \\
\text { keen. }\end{array}$ & $\begin{array}{l}\text { - Vaikuttaa jo julkais- } \\
\text { tun journalismin } \\
\text { sisältöön. } \\
\text { - Tuottaa henkistä } \\
\text { painetta ja käyttää } \\
\text { journalistin työ- } \\
\text { aikaa vaatimuksiin } \\
\text { vastaamiseen. } \\
\text { - Tuottaa organisaa- } \\
\text { tion sisäistä epä- } \\
\text { luottamusta ja } \\
\text { epävarmuutta. }\end{array}$ & $\begin{array}{l}\text { - Huolellinen pereh- } \\
\text { tyminen käsiteltä- } \\
\text { vään aiheeseen. } \\
\text { - Kiistakysymysten } \\
\text { ja vastaväitteiden } \\
\text { ennakointi. } \\
\text { - Avoimuus yleisön } \\
\text { suuntaan esim. } \\
\text { lähteiden osalta. } \\
\text { - Toimiva sisäinen } \\
\text { luottamus ja kom- } \\
\text { munikaatio organi- } \\
\text { saatiossa. }\end{array}$ \\
\hline Sanallinen painostus & $\begin{array}{l}\text { - Suora yhteydenotto } \\
\text { journalistiin, esi- } \\
\text { henkilöön tai tiedo- } \\
\text { tusvälineen omis- } \\
\text { tajaan painostus- } \\
\text { tarkoituksessa. }\end{array}$ & $\begin{array}{l}\text { • Vaikuttaa journa- } \\
\text { lismin sisältöön tai } \\
\text { estää julkaisu koko- } \\
\text { naan. } \\
\text { • Tuottaa jutun sisäl- } \\
\text { töön ja julkaisuun } \\
\text { kohdistuvaa hen- } \\
\text { kistä painetta. } \\
\text { • Tuottaa organisaa- } \\
\text { tion sisäistä epävar- } \\
\text { muutta ja epäluot- } \\
\text { tamusta. } \\
\text { • Vaikuttaa jatko- } \\
\text { juttuihin ja aiheen } \\
\text { käsittelyyn tulevai- } \\
\text { suudessa. }\end{array}$ & $\begin{array}{l}\text { - Ammatillisen etäi- } \\
\text { syyden säilyttämi- } \\
\text { nen ulkopuolisiin } \\
\text { toimijoihin. } \\
\text { - Kiistakysymysten } \\
\text { ja vastaväitteiden } \\
\text { ennakointi ja huo- } \\
\text { mioiminen. } \\
\text { - Toimiva sisäinen } \\
\text { luottamus ja kom- } \\
\text { munikaatio organi- } \\
\text { saatiossa. }\end{array}$ \\
\hline
\end{tabular}




\begin{tabular}{|c|c|c|c|}
\hline $\begin{array}{l}\text { Sanalliset } \\
\text { vihanilmaukset }\end{array}$ & $\begin{array}{l}\text { - Suora tai media- } \\
\text { välitteinen kontakti } \\
\text { journalistiin. } \\
\text { - Vihanilmausten } \\
\text { levittäminen julki- } \\
\text { sesti esim. verkko- } \\
\text { alustoilla. }\end{array}$ & $\begin{array}{l}\text { - Loukata, kuormit- } \\
\text { taa ja tuottaa nega- } \\
\text { tiivisia psykologisia } \\
\text { seurauksia journa- } \\
\text { listille. } \\
\text { • Vähentää journalis- } \\
\text { tin halua käsitellä } \\
\text { tiettyjä aiheita tai } \\
\text { näkökulmia tulevai- } \\
\text { suudessa. }\end{array}$ & $\begin{array}{l}\text { • Journalistin oman } \\
\text { julkisuuden ja yhte- } \\
\text { ystietojen saatavuu- } \\
\text { den rajoittaminen. } \\
\text { - Jutun julkaiseminen } \\
\text { työryhmän tai tie- } \\
\text { dotusvälineen } \\
\text { nimellä. } \\
\text { - Altistuksen vähen- } \\
\text { täminen tietoisella } \\
\text { välttelyllä sekä tek- } \\
\text { nisesti esim. yksi- } \\
\text { tyisyysasetuksia ja } \\
\text { blokkaamista hyö- } \\
\text { dyntäen. } \\
\text { - Vihanilmausten tal- } \\
\text { lentaminen ja asian } \\
\text { vieminen eteenpäin } \\
\text { oikeusteitse. }\end{array}$ \\
\hline $\begin{array}{l}\text { Julkinen } \\
\text { mustamaalaaminen }\end{array}$ & $\begin{array}{l}\text { - Valheellisten väit- } \\
\text { teiden, huhujen tai } \\
\text { yksityiselämään liit- } \\
\text { tyvien tietojen levit- } \\
\text { täminen julkisesti } \\
\text { mustamaalaus- } \\
\text { tarkoituksessa. } \\
\text { - Identiteettivarkau- } \\
\text { det ja valeprofiilien } \\
\text { luominen. }\end{array}$ & $\begin{array}{l}\text { • Tuottaa journalis- } \\
\text { tille henkilökoh- } \\
\text { taista maineriskiä. } \\
\text { • Vähätellä julkisesti } \\
\text { journalistin ammat- } \\
\text { titaitoa ja tämän } \\
\text { tekemän työn } \\
\text { uskottavuutta. } \\
\text { - Tuottaa organisaa- } \\
\text { tion sisäistä epävar- } \\
\text { muutta ja epäluot- } \\
\text { tamusta. } \\
\text { - Loukata ja kuormit- } \\
\text { taa journalistia sekä } \\
\text { tuottaa tälle nega- } \\
\text { tiivisia psykologisia } \\
\text { seurauksia. } \\
\text { - Vähentää journalis- } \\
\text { tin halua käsitellä } \\
\text { tiettyjä aiheita tai } \\
\text { näkökulmia tulevai- } \\
\text { suudessa. }\end{array}$ & $\begin{array}{l}\text { • Journalistin oman } \\
\text { julkisuuden ja } \\
\text { yhteystietojen saa- } \\
\text { tavuuden rajoitta- } \\
\text { minen. } \\
\text { - Jutun julkaisemi- } \\
\text { nen työryhmän tai } \\
\text { tiedotusvälineen } \\
\text { nimellä. } \\
\text { - Altistuksen vähen- } \\
\text { täminen tietoisella } \\
\text { välttelyllä sekä tek- } \\
\text { nisesti esim. yksi- } \\
\text { tyisyysasetuksia ja } \\
\text { blokkaamista hyö- } \\
\text { dyntäen. } \\
\text { - Julkiset tuen } \\
\text { ilmaukset, väittei- } \\
\text { siin vastaaminen } \\
\text { sekä omien tukiryh- } \\
\text { mien mobilisointi. } \\
\text { - Materiaalin tallen- } \\
\text { taminen ja asian } \\
\text { vieminen eteenpäin } \\
\text { oikeusteitse. }\end{array}$ \\
\hline $\begin{array}{l}\text { Journalistiin tai } \\
\text { tämän lähipiiriin } \\
\text { kohdistuva uhkailu }\end{array}$ & $\begin{array}{l}\text { - Suorien uhkaus- } \\
\text { ten tai uhalla vih- } \\
\text { jailun välittäminen } \\
\text { journalistin tietoon } \\
\text { tai asettaminen } \\
\text { esille julkisesti. }\end{array}$ & $\begin{array}{l}\text { - Heikentää journa- } \\
\text { listin, tämän lähi- } \\
\text { piirin ja työyhtei- } \\
\text { sön turvallisuuden- } \\
\text { tunnetta. } \\
\text { • Vähentää journalis- } \\
\text { tin halua käsitellä } \\
\text { tiettyjä aiheita tai } \\
\text { näkökulmia tulevai- } \\
\text { suudessa. }\end{array}$ & $\begin{array}{l}\text { - Journalistin oman } \\
\text { julkisuuden ja } \\
\text { yhteystietojen } \\
\text { rajoittaminen. } \\
\text { - Erilaiset turva- } \\
\text { toimet. } \\
\text { - Materiaalin tallen- } \\
\text { taminen ja asian } \\
\text { vieminen eteenpäin } \\
\text { oikeusteitse. }\end{array}$ \\
\hline
\end{tabular}




\begin{tabular}{|l|l|l|l|}
\hline Joukkoistettu & • Pyrkimykset mobi- & - Sisältää elementtejä & • Joukkoistetun häi- \\
häinintä & lisoida muita häirit- & sanallisesta painos- & rinnän saamista \\
& semään tai uhkaile- & tuksesta, vihanilma- & muodoista riippuen \\
& maan journalistia & uksista, julkisesta & vastakeinoina käy- \\
& tai tiedotusväli- & mustamaalaami- & tettiin yhdistel- \\
& nettä. & sesta sekä uhkai- & miä sanallisen pai- \\
& lusta. Tavoitteet & nostuksen, vihanil- \\
& tyypillisesti erilaisia & mausten, julkisen \\
& yhdistelmiä edellä & mustamaalaamisen \\
& mainittujen mene- & sekä uhkailun vas- \\
& telmien tavoitteista. & takeinoista. \\
\hline
\end{tabular}

Sanallisella painostuksella tarkoitan painostustarkoituksessa tehtyjä yhteydenottoja journalisteihin, näiden esihenkilöihin tai tiedotusvälineen omistajiin. Vaikka journalistien ja yhteiskunnallisten ja taloudellisten vallankäyttäjien välisen ammatillisen etäisyyden nähtiin yleisesti kasvaneen, erityisesti päätoimittajien koettiin edelleen olevan tietyissä tapauksissa alttiita vaikutusvaltaisten tahojen kulissien takaisille yhteydenotoille ja vaikutuspyrkimyksille (ks. myös Kunelius ym. 2010, 328-329).Alle poimitussa lainauksessa tutkiva journalisti kuvaa aikaisempia negatiivisia kokemuksiaan:

[...] kun hyvin verkostoituneiden ihmisten kanssa tai niistä ollaan tekemässä ikäviä juttuja niin sit vaan alkaa, tapahtua omituisia asioita ja projektit jotka on rullannu ihan hyvin lähiesimiehen kanssa nii ei enää rullaakaan niin hyvin ja.. Uskallan väittää että se on, et sitä tapahtuu paljonkin että noi isojen välineiden isot pomot jotka seurustelee sitte muiden isojen vallankäyttäjien kanssa niin kyl siellä kanssa näistä keskusteluu käydään. [...] Siis on päätoimittajia jotka näihin paineisiin reagoi. En tiä sitte että, tehdäkseen palveluksia kavereilleen vai aidosti uskoen sitä mitä heille kerrotaan, et toimittajat on väärillä jäljillä ja hukanneet fokuksensa ja mittasuhteet ja näin. Mutta et kyl se, se on se vaarallisin ja vaikuttavin ulkosen vaikuttamisen tapa. $\left(\mathrm{H}_{2} 8\right)$

Tällaisissa yhdistelmävaikuttamiseen tähtäävissä tilanteissa haastateltavat pitivät tärkeimpänä vastakeinona koko toimitusorganisaation kattavaa sitoutumista journalistiseen professionalismiin. Waisbord (2013, 10-11) määrittelee professionalismin keskeisimmäksi piirteeksi ammattikunnan kyvyn määritellä itse toimintaansa ohjaavat periaatteet ja toimia niiden mukaisesti. Professionalismin nähtiinkin haastatteluissa käytännössä ilmenevän periaatteellisessa pitäytymisessä päätösten tekemisessä vain ja ainoastaan journalistisin perustein sekä ammatillisen etäisyyden säilyttämisessä juttujen kohteisiin, lähteisiin ja yhteiskunnallisiin vallankäyttäjiin kaikissa tilanteissa. Näin journalistiseen komentoketjuun ei muodostu heikkoja kohtia, joihin ulkoiset toimijat voisivat iskeä väliin. Professionalismiin sitoutumisen nähtiin osaltaan myös vähentävän ulkoisten toimijoiden mahdollisuuksia aiheuttaa epävarmuutta journalistisen organisaation sisällä. Journalistit pystyivät luottamaan siihen, ettei journalistisesti perusteltuja juttuja muokata tai hyllytetä esimerkiksi liiketaloudellisista, poliittisista tai yhteiskunnallisiin valta-asemiin liittyvistä syistä (vrt. Kuutti 1995, 246-247). 
Joidenkin psykologisen vaikuttamisen menetelmien nähtiin kohdistuvan suoraan yksittäisiin journalisteihin ja tuottavan myös yksityiselämän puolelle ulottuvaa henkilökohtaista riskiä. Nykyisessä viestintäympäristössä esimerkiksi yksittäistä journalistia solvaavaa ja mustamaalaavaa materiaalia voidaan verkossa levittää nopeasti ja laajoille yleisöjoukoille, ja sen tuottamiseen voidaan pyrkiä mobilisoimaan erilaisia verkostoja ja yhteisöjä (ks. Rinne 2011). Merkittävä osa haastetaltavista koki juuri vihanilmausten ja mustamaalauksen potentiaalisesti saaman laajan julkisuuden merkittäväksi negatiiviseksi muutokseksi. Kokenut journalisti vertaa tilannetta aikaisempaan:

Se on erilaista kun loukkaukset ja väitteet on julkisesti näkyvillä verkossa. Yksityisesti sähköpostilla sitä sietää vaikka minkälaista puhetta, mutta kun tietää että ne tekstit on kaikkien luettavissa. $\left(\mathrm{H}_{3} \mathrm{O}\right)$

Henkilökohtaisiin hyökkäyksiin turvauduttiin journalistien mukaan erityisesti silloin, kun jutun faktoista tai prosesseista ei löydy virheitä tai heikkoja kohtia, joihin voitaisiin julkisuudessa tarttua. Tällöin pyrittiin iskemään yksittäisen journalistin maineeseen. Alle poimittu haastattelulainaus kuvaa näitä pyrkimyksiä:

[...] pyritään, rapauttamaan mun uskottavuuttani ja luotettavuuttani toimittajana eli siten että levitetään, yleensä se viesti on se et mä valehtelen. [...] mutta ei koskaan osoiteta että missä mä olisin valehdellut, eikä pyydetä oikaisuja ja muuta semmosta vaan se on semmost yleistä mustamaalausta, ja pyritään aiheuttaa semmost mainehaittaa. (H31)

Vaikka psykologisen vaikuttamisen menetelmillä ei välttämättä nähty olevan suoraa ja välitöntä vaikutusta journalismin sisältöön, ne koettiin usein henkilökohtaisesti kuormittavaksi. Varsinkin jatkuvan ja systemaattisen toiminnan tavoitteena nähtiin olevan työnteon tekeminen mahdollisimman epämukavaksi ja raskaaksi, jotta journalisti itse päätyisi vaihtamaan aiheitaan tai lähestymistapojaan (ks. Pöyhtäri ym. 2013, 133-137). Journalisti kuvaa käsitystään kokemansa psykologisen vaikuttamisen tavoitteista seuraavalla tavalla:

Siis ehkä tällasta vähän pelottelua, uuvuttamista mä sanoisin ehkä eniten et, sellasta [...] yritetty tehä mahollisimman vaikeaks se työnteko ja sellain viedä mun aikaani ja sitä kautta ehkä saada mut luopumaan jostaki asioista tai ainakin saada mut turhautumaan tai väsyneeks tai, saada mulle, joku julkinen rangaistus esimerkiks vaikka että saisin langettavan Julkisen sanan neuvostosta tai jotain täntyyppistä. (H11)

Yhteistä useimmille psykologisen vaikuttamisen menetelmille oli myös pyrkimys aiheuttaa epävarmuutta, epäluottamusta ja kitkaa journalististen organisaatioiden sisällä. Esimerkiksi solvaavaa ja mustamaalaavaa materiaalia voitiin levittää esihenkilöille ja työyhteisölle tarkoituksena leimata journalisti ammattitaidottomaksi, epäpäteväksi tai motiiveiltaan epäilyttäväksi ja näin hankaloittaa tämän työntekoa vahingoittamalla mainetta työyhteisössä. Tämän torjuminen edellyttää esihenkilöiltä ja työyhteisöltä herk- 
kyyttä tunnistaa ja kykyä suodattaa tällaisia vaikutuspyrkimyksiä. Alle poimittu lainaus kuvaa journalistin kokemuksia pyrkimyksistä horjuttaa hänen asemaansa tiedotusvälineessä:

Mun työnantajalle lähetetään jatkuvasti erilaisii diagnooseja mun mielenterveydestä muun muassa tai, valheita lähetetään että, mitä mä oon muka tehny [...] Jos kaikki ei alkais olemaan mun kohdalla jo hyvin vakuuttuneita siitä että, tai tietosii siit et, mun kohdalla tämmönen on selkeesti valetta. [...] Niin siihen menis kauheesti aikaa niihin selvityksiin. $\left(\mathrm{H}_{3}\right)$

Aikaisemmassa tutkimuksessa jatkuvan ja laajamittaisen painostamisen, vihanilmausten ja uhkailun on havaittu journalistien kohdalla johtavan useisiin negatiivisiin psykologisiin seurauksiin, ja ilmiötä voidaan perustellusti kuvata psykologiseksi väkivallaksi (Clark \& Grech 2017, 12-13). Useat journalistit kokivat, että heihin yksityishenkilöinä kohdistetulla loukkaamisella, häirinnällä, mustamaalaamisella ja uhkailulla pyrittiin tosiasiassa välillisesti vaikuttamaan heidän toimintaansa ammattiroolissa. Lainaus alla kuvaa tätä:

[...] ne ei pysty iskemään mun ammattihenkilöön. Sitä ei, meil on kaikilla todella kova kuori, se ammattikuori. [...] Mut mihin ne pääsee käsiks on yksityishenkilö, koska sillä on paljon pehmeämpi se suojakuori, sil yksityisellä ihmisellä.[...] Et murtamalla sen yksityisen henkilön psyykkeen, sen henkisen kantin, päästään käsiksi siihen ammattihenkilöön. Elikkä saadaan se ihminen tekemään yksityishenkilön, yksityishenkilönä päätös esimerkiks luopua siitä ammatista. Tai valita toisin juttuaiheet tai siirtyy tekemään toisenlaisii kokonaan hommia [...]. ( $\left.\mathrm{H}_{3}\right)$

Vahva ammattirooli ja sen koetut vaatimukset saattoivat myös altistaa journalisteja uupumukselle ja muille negatiivisille psykologisille seurauksille yksityiselämässä. Alana journalismia on leimannut kova maskuliininen eetos, jossa on korostettu kovanahkaisuutta, taipumattomuutta ja alistumattomuutta ulkoisille auktoriteeteille (Ross \& De Bruin 2004). Moni haastatelluista korostikin ammattirooliaan ja koki ammatilliseksi velvollisuudekseen jatkaa valitsemiensa aiheiden parissa työskentelyä psykologisesta väkivallasta ja uhkailusta sekä mahdollisista yksityiselämän puolelle ulottuvista seurauksista huolimatta. Tämä paine voi olla erityisen kova esihenkilöasemassa, jossa alaisten ja journalismin suojaamisen ulkoiselta vaikuttamiselta ja painostukselta voidaan nähdä kuuluvan erityisen vahvasti ammattiroolin vaatimuksiin (Revers 2017, 162-165). Jännite koettujen vaatimusten, jaksamisen ja tarpeiden välillä voi olla yksilölle hyvin kuormittava. Alle poimitussa lainauksessa häirinnän kohteeksi johtotehtävissä toimiessaan joutunut journalisti kuvaa omaa kokemustaan:

[...] totta kai sitten koki tosi paljon vastuuta yhteisölle ja toimittajille, omille työntekijöilleen että koitti olla vahva heidän takiaan, ja että he uskaltais jatkaa sitä työtä mitä siellä varsinkin tuli, niinä vuosina tuli meille tosi paljon nuoria uusia toimittajia ja uusia kykyjä, ja sitten nää jotkut tämmöset veteraanitoimittajat halus myöskin nostaa profiliaan ja halus tehdä aktiivisempaa ja, niinku ehkä rohkeampaa journalismia niin totta kai koitti olla sil- 
leen hieman niinku esikuva heille ja että niinku kestää ja olla vahva. Että ei se nyt oo kauhean helppoa siinä asemassa sitten myöntää että, tämä sattuu ja tää vaikuttaa minuun ja, on niinku vaikeaa. (H26)

Vastakeinona psykologisen vaikuttamisen menetelmille journalistit käyttivät toisinaan yleisövuorovaikutuksen välttämistä sekä henkilökohtaisen julkisuuden ja suorien yhteydenottomahdollisuuksien rajoittamista. Journalistit saattoivat esimerkiksi vetäytyä sosiaalisen median ympäristöistä. Tämä viestii siitä, että tietynlaisen julkisuuden ja näkyvyyden koettiin altistavan journalisteja esimerkiksi vihanilmauksille, mustamaalaamiselle ja uhkailulle (ks. Pöyhtäri ym. 2013, 152-154). Kontaktien rajoittamista pidettiin kuitenkin myös ongelmallisena sillä se heikensi esimerkiksi potentiaalisten lähteiden mahdollisuuksia ottaa suoraan yhteyttä journalisteihin. Moni haastateltavista myös mielsi sosiaalisen median tärkeäksi työympäristöksi ja työvälineeksi, jota käytettiin yleisöjen tavoittamiseen ja oman ammatillisen brändin rakentamiseen. Häirinnän kohteeksi joutuminen saattaa siis pakottaa journalistin punnitsemaan erilaisten toimintamallien hyötyjä ja haittoja. Chenin ja kumppanien (2018) tutkimuksessa naisjournalistit kuvasivat joutuvansa verkkoympäristössä valitsemaan sukupuolittuneelle häirinnälle altistavan yleisövuorovaikutuksen tai siitä pidättäytymisen välillä. Koska työnantajat kannustivat voimakkaasti vuorovaikutukseen, naisjournalistit kokivat vuorovaikutuksen välttämisen heikentävän heidän uramahdollisuuksiaan.

Tämän tutkimuksen teemahaastatteluissa journalistit korostivat erityisesti luottamuksen, kommunikaation ja tuen merkitystä psykologisen vaikuttamisen vastakeinona. Journalististen organisaatioiden sisäisen luottamuksen ja kommunikaation nähtiin olevan avainasemassa siinä, etteivät ulkopuoliset toimijat kyenneet painostamalla horjuttamaan tai kyseenalaistamaan journalistien ammattitaitoa, integriteettiä tai asemaa työyhteisön silmissä. Luottamuksen ollessa kunnossa journalistit kokivat pystyvänsä vapaasti myös raportoimaan vaikutusyrityksistä ja ohjaamaan niitä tarvittaessa esihenkilöidensä käsiteltäväksi oman työrauhansa takaamiseksi (ks. Revers 2017, 162-165).

Journalistien joutuessa kokemaan henkistä väkivaltaa tai uhkaa, sisäisen luottamuksen koettiin mahdollistavan sen, että asia otetaan organisaatiossa vakavasti ja että journalistit uskaltavat ja haluavat tarvittaessa turvautua tarjottuun apuun ja tukitoimiin. Tästä journalisteilla oli kaksijakoisia kokemuksia. Osa psykologisen väkivallan ja uhan kohteeksi joutuneista haastateltavista koki saaneensa kaiken mahdollisen tuen työnantajan ja organisaation puolelta. Osalla kokemukset olivat päinvastaisia, ja he olivat kohdanneet vähättelyä ja ymmärtämättömyyttä raportoidessaan kokemuksistaan eteenpäin:

[...] nää jotka on uutispäälliköinä tai päätoimittajina sanoo että me ei saada antaa valtaa näille [...]. Mut se on heidän hyvin helppo sanoa, koska he ei oo henkilökohtasesti siinä vastaanottamassa tätä. Mä muistan ku mulle tuli ensimmäinen tappouhkaus niin sillonen uutispäällikkö [...] hän oli jotenki kauheen innossaan siitä et oo wow, että nyt tää tappouhkaus et joku on huomannu meiätki. Eikä ne ottanu ollenkaa huomioon sitä et sehän kohdistu minuun henkilönä, eikä se ollu, siin ei ollu tukee millään tasolla. (H29) 
On myös syytä huomioida, että journalisteihin julkisesti kohdistettua uhkailua ja häirintää voidaan tulkita koko tiedotusvälineelle ja laajemmin koko journalistikunnalle osoitettuna viestinä (Hiltunen 2019, 18). Myös ne haastateltavat, joilla ei ollut omakohtaista kokemusta häirinnän kohteeksi joutumisesta, olivat häirinnästä hyvin tietoisia ja toivat oma-aloitteisesti esiin kollegoilleen tapahtuneita tai julkisuudessa esillä olleita tapauksia (ks. myös. Pöyhtäri ym. 2013, 135-136).

\section{3) Fyysiset menetelmät}

Fyysisiin ulkoisen vaikuttamisen menetelmiin luokittelen kuuluvaksi journalistisen työn häiritsemisen tai estämisen fyysisessa tilassa, työvälineisiin tai omaisuuteen kohdistuvan vahingonteon ja fyysisen väkivallan. Nämä on kuvattu taulukossa 5 .

Taulukko 5. Fyysiset ulkoisen vaikuttamisen menetelmät.

\begin{tabular}{|c|c|c|c|}
\hline $\begin{array}{l}\text { Vaikuttamisen } \\
\text { menetelmä }\end{array}$ & $\begin{array}{l}\text { Tyypilliset } \\
\text { toteutustavat }\end{array}$ & $\begin{array}{l}\text { Vaikuttamisen } \\
\text { tavoitteet }\end{array}$ & $\begin{array}{l}\text { Journalistin } \\
\text { vastakeinot }\end{array}$ \\
\hline $\begin{array}{l}\text { Työnteon } \\
\text { häiritseminen tai } \\
\text { estäminen }\end{array}$ & $\begin{array}{l}\text { • Journalistisen työn } \\
\text { vaikeuttaminen tai } \\
\text { estäminen häiritse- } \\
\text { vällä tai uhkaavalla } \\
\text { käytöksellä fyysi- } \\
\text { sessä tilassa. }\end{array}$ & $\begin{array}{l}\text { • Vaikeuttaa ja häiritä } \\
\text { työn tekemistä ja } \\
\text { estää journalistinen } \\
\text { raportointi julkisuu- } \\
\text { teen. } \\
\text { - Heikentää journalis- } \\
\text { tin turvallisuuden- } \\
\text { tunnetta, ja viestiä, } \\
\text { ettei media ole ter- } \\
\text { vetullut paikalle. }\end{array}$ & $\begin{array}{l}\text { - Etukäteen tehtävä } \\
\text { tilannearvio- ja } \\
\text { suunnitelma. } \\
\text { • Turvatoimet ja työs- } \\
\text { kentely pareittain } \\
\text { tai ryhmässä. }\end{array}$ \\
\hline Vahingonteko & $\begin{array}{l}\text { - Työvälineisiin, työ- } \\
\text { tiloihin tai journa- } \\
\text { listin henkilökohtai- } \\
\text { seen omaisuuteen } \\
\text { kohdistuva vahin- } \\
\text { gonteko. }\end{array}$ & $\begin{array}{l}\text { • Vaikeuttaa journa- } \\
\text { listisen työn teke- } \\
\text { mistä. } \\
\text { • Heikentää journa- } \\
\text { listin, tämän lähi- } \\
\text { piirin sekä työyhtei- } \\
\text { sön turvallisuuden- } \\
\text { tunnetta. }\end{array}$ & $\begin{array}{l}\text { - Erilaiset } \\
\text { turvatoimet. }\end{array}$ \\
\hline Väkivalta & $\begin{array}{l}\text { - Journalistiin kohdis- } \\
\text { tuva fyysinen väki- } \\
\text { valta. }\end{array}$ & $\begin{array}{l}\text { - Keskeyttää journa- } \\
\text { listisen työn tekemi- } \\
\text { nen väkivaltaisesti } \\
\text { ja pakottaa journa- } \\
\text { listi poistumaan pai- } \\
\text { kalta. } \\
\text { - Heikentää journalis- } \\
\text { tin turvallisuuden- } \\
\text { tunnetta, ja viestiä, } \\
\text { ettei media ole ter- } \\
\text { vetullut paikalle. }\end{array}$ & $\begin{array}{l}\text { - Etukäteen tehtävä } \\
\text { tilannearvio- ja } \\
\text { suunnitelma. } \\
\text { • Turvatoimet ja työs- } \\
\text { kentely pareittain } \\
\text { tai ryhmässä. }\end{array}$ \\
\hline
\end{tabular}


Häiritsevää ja uhkaavaa käytöstä journalistit olivat kokeneet erityisesti mielenosoitusten, oikeudenkäyntien sekä poikkeuksellisten uutistilanteiden yhteydessä. Oikeudenkäynneistä raportoinnin yhteydessä journalistit olivat joutuneet sanallisesti uhatuksi sekä uhkaavien lähestymisten ja eleiden kohteeksi. Mielenosoitukset, yleisötapahtumat ja tilanteet, joissa journalistit työskentelevät levottomassa ympäristössä ja kohtaavat voimakkaiden tunteiden vallassa olevia ihmisiä, on aikaisemmassa tutkimuksessa tunnistettu riskitekijöiksi journalisteihin kohdistuvalle fyysiselle uhalle (Kodellas ym. 2014). Yhtä tähän tutkimukseen haastatelluista journalisteista oli mielenosoitustilanteessa yritetty heittää raskaalla esineellä ja toista tahallisesti kaataa maahan.

Useat haastatelluista journalisteista nostivat esiin impulsiivisen väkivallan uhan. Kun journalistit ovat yhä enemmän esillä omilla kasvoillaan ja henkilöinä (esim. Lehtonen 2013; Koljonen \& Reunanen 2014), heidät tunnistetaan aiempaa useammin kadulla ja julkisissa tiloissa. Työhön kohdistuvat mahdolliset uhat voivat näin herkemmin heijastua myös yksityiselämän puolelle. Journalistit kertoivat muun muassa seuraamisesta ja eriasteisesta uhkaavasta käytöksestä. Yksi haastatelluista oli joutunut pahoinpitelyn uhriksi anniskeluravintolassa, kun median toiminnasta hermostunut henkilö oli lyönyt tätä nyrkillä. Muutamilla oli kokemusta läheltä piti -tilanteista, joissa sivulliset henkilöt olivat ehtineet uhkaavaan tilanteeseen väliin.

Uuden viestintäympäristön koettiin edesauttavan verkossa tapahtuvan häirinnän, uhkailun ja mustamaalauksen siirtymistä fyysiseen tilaan (ks. Pöyhtäri ym. 2013, 129131). Verkon välityksellä voidaan julkisesti yllyttää suurta yleisöä häiritsevään ja uhkaavaan käytökseen sekä konkreettisesti edistää tätä esimerkiksi jakamalla tietoa henkilöstä ja tämän liikkeistä. Tällaisen kohteeksi joutunut journalisti kuvaa lainauksessa kokemuksiaan verkkokeskusteluista:

[...] nimettömillä keskustelupalstoilla oli [...] ollu sitten havaintoja siitä että missä mä oon liikkunu ja mitä mä oon tehny ja niin pois päin, et jotenki kiinnostavaa et joku vaivaantuu tarkkailemaan tällä tavalla. (H29)

Osa journalisteista oli vähentänyt julkisilla paikoilla liikkumista ja pyrkinyt välttämään sellaisia ympäristöjä, joissa heidät voitiin tunnistaa. Työn seurausten liukumisella henkilökohtaisen elämän puolelle oli myös vaikutusta journalistien lähipiiriin (ks. myös Pöyhtäri ym. 2013, 132). Alla journalisti kuvaa häiritsevän ja uhkaavan käytöksen vaikutusta perhe-elämäänsä:

Vielä vois sanoo ton että esimerkiksi sillä on ollut lapseen vaikutus. Se täytyy sanoa että kun johonkin on lapsen kanssa mennyt niin joskus on törmännyt siihen että joku on käynyt huutamaan suupäänä niin sehän on lapsesta aika omituista. Tällästä on sattunut useita kertoja. (H21)

Fyysisiin uhkiin voitiin tarvittaessa vastata proaktiivisesti ennakkosuunnittelulla, varautumisella ja turvatoimilla sekä työskentelemällä pareittain tai ryhmässä. Turvatoimet saattavat kuitenkin vaikeuttaa ja rajoittaa journalistien työntekoa sekä mahdollisuuksia elää normaalia yksityiselämää. 


\section{4) Institutionaaliset menetelmät}

Institutionaaliseksi vaikuttamiseksi luokittelin kaikki sellaiset vaikuttamisen menetelmät, joissa käytetään hyväksi yhteiskunnallisia instituutioita. Institutionaaliseksi vaikuttamiseksi määrittelin esimerkiksi painostustarkoituksessa Julkisen sanan neuvostoon tehdyt kantelut, viranomaiskantelut sekä oikeusjutut ja vahingonkorvausvaatimukset. Näiden lisäksi institutionaaliseen vaikuttamiseen kuuluvat viranomaisten käyttämät pakkokeinot silloin, kun niillä on tarkoitus vaikuttaa journalismin autonomiaan ja journalistisen työn mahdollisuuksiin. Institutionaalisen vaikuttamisen menetelmät ja vastakeinot on tiivistetty taulukkoon 6 .

Taulukko 6. Institutionaaliset ulkoisen vaikuttamisen menetelmät.

\begin{tabular}{|c|c|c|c|}
\hline $\begin{array}{l}\text { Vaikuttamisen } \\
\text { menetelmä }\end{array}$ & $\begin{array}{l}\text { Tyypilliset } \\
\text { toteutustavat }\end{array}$ & $\begin{array}{l}\text { Vaikuttamisen } \\
\text { tavoitteet }\end{array}$ & $\begin{array}{l}\text { Journalistin } \\
\text { vastakeinot }\end{array}$ \\
\hline $\begin{array}{l}\text { Kanteleminen } \\
\text { Julkisen sanan } \\
\text { neuvostoon } \\
\text { painostus- } \\
\text { tarkoituksessa }\end{array}$ & $\begin{array}{l}\text { - Uhkaaminen JSN- } \\
\text { kantelulla tai kante- } \\
\text { lun tekeminen } \\
\text { painostus- } \\
\text { tarkoituksessa. }\end{array}$ & $\begin{array}{l}\text { - Tuottaa sisäistä pai- } \\
\text { netta, epävarmuutta } \\
\text { ja epäluottamusta } \\
\text { journalistisessa orga- } \\
\text { nisaatiossa. }\end{array}$ & $\begin{array}{l}\text { - Journalistin ohjeiden } \\
\text { tunteminen ja } \\
\text { huolellinen } \\
\text { seuraaminen. }\end{array}$ \\
\hline Viranomaiskantelut & $\begin{array}{l}\text { - Uhkaaminen kante- } \\
\text { luiden tekemisestä } \\
\text { erilaisille viran- } \\
\text { omaistahoille tai } \\
\text { kanteluiden teke- } \\
\text { minen painostus- } \\
\text { tarkoituksessa. }\end{array}$ & $\begin{array}{l}\text { - Tuottaa sisäistä pai- } \\
\text { netta, epäluottamus- } \\
\text { ta ja epävarmuutta } \\
\text { journalistisessa orga- } \\
\text { nisaatiossa. } \\
\text { - Käynnistää mahdolli- } \\
\text { sesti työaikaa ja } \\
\text { resursseja kuluttavia } \\
\text { prosesseja. }\end{array}$ & $\begin{array}{l}\text { - Lainsäädännön ja } \\
\text { viranomaisten } \\
\text { toimivaltuuksien } \\
\text { tunteminen. }\end{array}$ \\
\hline $\begin{array}{l}\text { Oikeusjutut ja } \\
\text { vahingonkorvaus- } \\
\text { vaatimukset }\end{array}$ & $\begin{array}{l}\text { - Uhkaukset oikeus- } \\
\text { jutuista tai vahin- } \\
\text { gonkorvausvaati- } \\
\text { muksista. } \\
\text { - Tutkintapyyntöjen } \\
\text { tekeminen. } \\
\text { - Suorien korvaus- } \\
\text { vaatimusten lähettä- } \\
\text { minen. }\end{array}$ & $\begin{array}{l}\text { - Aiheuttaa journalis- } \\
\text { tiseen prosessiin } \\
\text { taloudellisen tai } \\
\text { oikeudellisen riskin } \\
\text { mahdollisuus. } \\
\text { - Tuottaa organisaa- } \\
\text { tion sisäistä painetta, } \\
\text { epävarmuutta ja } \\
\text { epäluottamusta. } \\
\text { - Käynnistää työaikaa } \\
\text { ja resursseja kulutta- } \\
\text { via prosesseja. }\end{array}$ & $\begin{array}{l}\text { - Journalismille keskei- } \\
\text { sen lainsäädännön ja } \\
\text { sen tulkinnan tunte- } \\
\text { minen. } \\
\text { - Juttujen tarkistutta- } \\
\text { minen etukäteen } \\
\text { journalistisen } \\
\text { organisaation } \\
\text { omilla juristeilla. }\end{array}$ \\
\hline Pakkokeinot & $\begin{array}{l}\text { - Lain suomien pakko- } \\
\text { keinojen kohdista- } \\
\text { minen journalistiin, } \\
\text { tiedotusvälineeseen } \\
\text { tai näiden keskeisiin } \\
\text { lähteisiin. } \\
\text { - Pyrkimykset murtaa } \\
\text { lähdesuoja pakkokei- } \\
\text { noilla tai haastamal- } \\
\text { la journalisti todista- } \\
\text { jaksi oikeuteen. }\end{array}$ & $\begin{array}{l}\text { - Murtaa journalistien } \\
\text { lähdesuoja. } \\
\text { - Pelotella lähteet } \\
\text { hiljaisiksi. } \\
\text { - Estää määrättyjen } \\
\text { aiheiden journalisti- } \\
\text { nen tarkastelu. }\end{array}$ & $\begin{array}{l}\text { - Pakkokeinojen mah- } \\
\text { dollisuuden huomioi- } \\
\text { minen ja niihin } \\
\text { varautuminen. } \\
\text { - Lähdesuojan turvaa- } \\
\text { minen poikkeukselli- } \\
\text { silla järjestelyillä. }\end{array}$ \\
\hline
\end{tabular}


Myös institutionaalisen vaikuttamisen osalta rajanveto on vaikeaa, sillä kantelut ja rikosilmoitukset ovat sinällään hyväksyttäviä tapoja asettaa mahdollisia väärinkäytöksiä tai rikoksia tutkittavaksi. Niitä tai niiden uhkaa voidaan kuitenkin tietoisesti käyttää journalismin kohdistuvan vaikuttamisen ja painostuksen välineinä, mikä perustelee niiden tarkastelemisen tässä kontekstissa. Esimerkiksi Julkisen sanan neuvosto on itse julkisesti ilmoittanut, että se pyrkii karsimaan kaikki kiusaamis- ja häirintätarkoituksessa tehdyt kantelut (JSN 2016).

Institutionaalisen vaikuttamisen vastakeinoina mainittiin usein Journalistin ohjeiden sekä journalismin näkökulmasta keskeisen lainsäädännön ja sen tulkinnan tuntemus. Lainsäädäntötuntemuksen katsottiin suojaavan erityisesti institutionaaliseen vaikuttamiseen liittyvältä pelotevaikutukselta. Kun journalisti pystyy toteamaan esimerkiksi tutkintapyynnöt tai korvausvaatimukset sellaisiksi, ettei niillä ole todellisuudessa mahdollisuutta menestyä, tavoiteltu pelotevaikutus menettää tehoaan. Silti näistä menetelmistä voi seurata kuormitusta journalistin työhön. Kokenut oikeustoimittaja kuvaa erään oman tapauksensa vaikutusta näin:

[...] tuli vahingonkorvauskanneuhkaus. Puhuttiin miljoonakanteesta mikä nyt kuulostaa ehkä vähän ylimitotetulta mut toisaalt, kun tiedettiin myöskin että, tää ihminen on niitä tehny, nii kylhän se vaikuttaa vaikka tietää, että sillä kanteel ei oo läpimenomahdollisuuksii, mutta kun tietää et se aiheuttaa kuitenki työtä ja vaivaa, nii totta kai se häiritsee tuolla mieles mut ei vaikuta kyllä siihen työhön mä oon sitte tämänki keissin kans jatkanu. Mut kyllähän se jossain, kaivertaa ja rasittaa. (H24)

Oikeudenkäynteihin liittyvä taloudellinen ja oikeudellinen riski sekä työläät ja aikaa vievät oikeusprosessit muodostavat erityisen riskintekijän freelancereille, joiden ei välttämättä ole mahdollista saada näihin tukea työnantajalta. Lisäksi toimittajia voidaan tutkintapyynnöillä pyrkiä tekemään "osallisiksi" uutisoitavista tapahtumista ja tällä perusteella esittää vaatimuksia näiden jääväämisestä tapauksen journalistisesta käsittelystä (esim. Liski 2020).

\section{5) Taloudelliset menetelmät}

Taloudelliseen vaikuttamiseen luokittelen kuuluviksi tiedotusvälineeseen kohdistuvat positiiviset ja negatiiviset taloudelliset sanktiot sekä pyrkimykset vaikuttaa journalismin sisältöön journalisteihin kohdistetulla lahjonnalla. Nämä menetelmät on kirjattu taulukkoon 7 . 
Taulukko 7. Taloudelliset ulkoisen vaikuttamisen menetelmät.

\begin{tabular}{|c|c|c|c|}
\hline $\begin{array}{l}\text { Vaikuttamisen } \\
\text { menetelmä }\end{array}$ & $\begin{array}{l}\text { Tyypilliset } \\
\text { toteutustavat }\end{array}$ & $\begin{array}{l}\text { Vaikuttamisen } \\
\text { tavoitteet }\end{array}$ & $\begin{array}{l}\text { Journalistin } \\
\text { vastakeinot }\end{array}$ \\
\hline $\begin{array}{l}\text { Taloudelliset } \\
\text { sanktiot }\end{array}$ & $\begin{array}{l}\text { - Tiedotusvälinee- } \\
\text { seen kohdistettujen } \\
\text { taloudellisten sank- } \\
\text { tioiden tai niiden } \\
\text { uhan käyttäminen } \\
\text { vaikutuspyrkimyk- } \\
\text { sissä. }\end{array}$ & $\begin{array}{l}\text { - Käyttää taloudel- } \\
\text { lista valtaa journa- } \\
\text { lismin sisältöihin } \\
\text { vaikuttamiseen. } \\
\text { - Luoda korkeampaa } \\
\text { kynnystä suurien il- } \\
\text { moittajien tai rahoi- } \\
\text { tuksesta päättävien } \\
\text { tahojen käsittelemi- } \\
\text { seen negatiivisissa } \\
\text { yhteyksissä. }\end{array}$ & $\begin{array}{l}\text { - Journalismin ja } \\
\text { liiketoiminnan erot- } \\
\text { tavan palomuurin } \\
\text { ylläpitäminen. }\end{array}$ \\
\hline Lahjonta & $\begin{array}{l}\text { - Taloudellisesti mer- } \\
\text { kittävien etujen } \\
\text { tai lahjojen tarjoa- } \\
\text { minen vastineeksi } \\
\text { mahdollisuudesta } \\
\text { vaikuttaa journalis- } \\
\text { tiseen sisältöön. }\end{array}$ & $\begin{array}{l}\text { Vaikuttaa journalis- } \\
\text { miin taloudellisen } \\
\text { suostuttelun avulla. }\end{array}$ & $\begin{array}{l}\text { - Etuja ja lahjoja } \\
\text { koskevat sisäiset } \\
\text { linjaukset ja ohjeet. } \\
\text { - Kategorinen kiel- } \\
\text { täytyminen ulko- } \\
\text { puolelta tulevista } \\
\text { eduista ja lahjoista. }\end{array}$ \\
\hline
\end{tabular}

Välineen koko, rahoitus ja resurssit vaikuttavat yleisesti tiedotusvälineiden kykyyn vastustaa taloudellisia sanktioita. Mitä riippuvaisempia välineet ovat mainosrahoitteisuudesta ja pienestä joukosta ilmoittajia, sitä alttiimpia ne ovat taloudelliselle painostukselle. (Kuutti 1995, 248-250.) Haastattelumateriaalin perusteella taloudellisilla sanktioilla uhkailua ei valtakunnallisissa välineissä yleensä pidetty kovinkaan merkittävänä tekijänä mainostajien suuren määrän takia. Haastateltu journalisti kuvaa tilannetta valtakunnallisen kaupallisen televisiokanavan näkökulmasta:

[...] mainostajia oli niin hirveesti, että jos sä oisit ryhtyny tekemään juttuja sillä tavalla että mainostajien lista vasemmassa kädessä että ketä ei saa loukata, niin sitten ois pitäny heti raakata hirvee määrä aiheita pois koska, VR mainostaa, ei voi tehdä VR:stä, Finnair mainostaa, ei voi tehdä Finnairista, vaalimainontaa ei voi tehdä puolueet, ei tommosta ajattelua harrastettu siellä mun toimituksessa ainakaan. (H18)

Heikoimmassa asemassa olivat pelkkien mainostulojen varassa olevat tai niistä hyvin riippuvaiset kaupunki- ja paikallislehdet, joissa taloudellinen painostus saattoi toisinaan vaikuttaa konkreettisesti journalismin aihevalintoihin (ks. myös Pöyhtäri ym. 2016, 10). Tiedotusvälineen omat taloudelliset edut saattoivat suuria ilmoittajia käsitellessä asettua konkreettisesti ristiriitaan yleisön tiedonsaantioikeuden ja journalistisen etiikan kanssa. Tällaisissa tilanteissa journalistisen työn ja liiketoiminnan erottavan palomuurin pitävyys taloudellisen vaikuttamisen vastakeinona korostui. Kaikissa välineissä tämä raja ei journalistien mukaan ollut selvä. Lainauksessa tällai- 
sessa lehdessä työskentelevä journalisti kuvaa juttuprosessia, josta joutui luopumaan päätoimittajan määräyksellä, kun jutun kohteeksi paljastui tiedotusvälineen omistavaan yhtiöön kytkeytyvä yritys:

Näitä tilanteita tulee mainosrahoitteisissa medioissa varmasti paljon vastaan, niin kuin valitettavasti meilläkin. Toimittajan ammattietiikan kannalta ne ovat erittäin ikäviä. Ainakin jos pyrkii noudattamaan journalistin ohjeita ja haluaa olla hyvä sekä luotettava journalisti. Itseäni tämä tilanne harmittaa paljon, koska tässä oli erittäin hyvä juttu noin ammatillisessa mielessä sekä myös lukijoiden kannalta ja nyt en voikaan sitä tehdä. [...] Koen, että petän lukijoiden luottamuksen, vaikka he eivät sitä tietäisikään. Minulla on tieto niin sanotusta yhteiskunnallisesta epäkohdasta ja en voi tuoda sitä julki, vaikka juuri sitä varten työni ja toimittajan ammattinimike on olemassa. Toisaalta en tietenkään halua oman ja muiden työpaikan vaarantuvan ja ymmärrän, miksi emme juttua tee. $\left(\mathrm{H}_{15}\right)$

Haastatellut journalistit toivat esille vastaavaa turhautumista ja ristiriitaisia tunteita kuvatessaan tilanteita, joissa he olivat kokeneet, etteivät he voineet toimia journalististen periaatteiden mukaisesti. Nämä kuvaukset vahvistavat osaltaan havaintoa professionalismin ja autonomian keskeisestä merkityksestä suomalaisten journalistien ammatillisessa itseymmärryksessä (Pöyhtäri ym. 2014, 26; Pöyhtäri ym. 2016). Samanaikaisesti ne havainnollistavat, kuinka vaikeaa yhdistelmävaikuttamisen torjuminen on tilanteissa, joissa journalistinen organisaatio ei tue tätä tavoitetta (ks. myös. Kuutti 1995, 248).

Erilaisten etujen, kestitysten ja lahjojen tarjoamisen koettiin vähentyneen merkittävästi aikaisempaan verrattuna. Tätä pidettiin yleisesti terveenä kehityksenä journalismin näkökulmasta. Joissakin tiedotusvälineissä oli myös vastakeinona laadittu yhteisiä periaatteita ja ohjeita etujen ja lahjojen vastaanottamisesta. Muutamilla haastatelluista oli kokemusta kutsuista ja tarjouksista, joita he pitävät lahjonnan kaltaisina vaikuttamisyrityksinä:

Kyllähän joskus on ollut sellasta lahjontaan viittaavaa että joku hyvä esimerkki että kaupungilla kun tuli arka asia esille ne kutsuivat katsomaan [...] peliä aitioon. Pyrkivät vaikuttamaan ennakolta siihen että miten sitä heidän asiaa minkä he tiesivät että kertoo siitä että on töpätty oikein kunnolla niin sen käsittelyä uskovat et se muuttaa jollakin tavalla. [...] $\left(\mathrm{H}_{21}\right)$

\section{6) Tietotekniset menetelmät}

Tietotekniseksi vaikuttamiseksi määrittelen menetelmät, jotka kohdistuvat journalistien tietoteknisiin työvälineisiin ja tapahtuvat pääasiassa tietoverkkojen välityksellä. Nämä kattavat esimerkiksi verkkovakoilun, erilaiset verkkohyökkäykset sekä pyrkimykset murtautua tiedotusvälineiden järjestelmiin tai journalistien sähköposteihin, viestintävälineisiin tai sosiaalisen median profiileihin. Nämä on kuvattu taulukossa 8. 
Taulukko 8. Tietotekniset ulkoisen vaikuttamisen menetelmät.

\begin{tabular}{|c|c|c|c|}
\hline $\begin{array}{l}\text { Vaikuttamisen } \\
\text { menetelmä }\end{array}$ & $\begin{array}{l}\text { Tyypilliset } \\
\text { toteutustavat }\end{array}$ & $\begin{array}{l}\text { Vaikuttamisen } \\
\text { tavoitteet }\end{array}$ & $\begin{array}{l}\text { Journalistin } \\
\text { vastakeinot }\end{array}$ \\
\hline $\begin{array}{l}\text { Tietomurrot ja } \\
\text { verkkovakoilu }\end{array}$ & $\begin{array}{l}\text { - Yritykset murtautua } \\
\text { teknisesti verkko- } \\
\text { palveluihin sekä eri- } \\
\text { laiset kalastelu- ja } \\
\text { verkkohyökkäykset. }\end{array}$ & $\begin{array}{l}\text { - Saada käsiin arka- } \\
\text { luontoista tietoa, } \\
\text { esim. journalistien } \\
\text { lähteitä. } \\
\text { • Saada journalistin } \\
\text { yksityiselämästä } \\
\text { tietoa, jota voidaan } \\
\text { käyttää julkisessa } \\
\text { mustamaalaami- } \\
\text { sessa. } \\
\text { • Vakoilla journalis- } \\
\text { tin ja tiedotusväli- } \\
\text { neen toimintaa sekä } \\
\text { sisäistä viestintää. }\end{array}$ & $\begin{array}{l}\text { - Tietoturvasta huo- } \\
\text { lehtiminen. } \\
\text { - Kalastelu- ja verk- } \\
\text { kohyökkäysten tak- } \\
\text { tiikoihin perehtymi- } \\
\text { nen. }\end{array}$ \\
\hline
\end{tabular}

Tietoteknisen vaikuttamisen menetelmiä voidaan käyttää tiedonhankinnan ja seurannan välineenä, ja näin saatavalla informaatiolla voidaan pyrkiä tehostamaan muuntyyppisiä vaikuttamisen menetelmiä. Lisäksi esimerkiksi verkkohyökkäykset saattavat kohdistua koko tiedotusvälineeseen yksittäisen journalistin sijasta, ja vastuu niiden torjumisesta on tällaisissa tilanteissa usein pääasiassa tiedotusvälineen teknisellä henkilöstöllä. Tietoteknisen vaikuttamisen tunnistaminen voi pyrkimysten onnistumisesta riippumatta olla vaikeaa ja edellyttää laajaa tietoteknistä osaamista. Näin ollen vain erittäin harvoilla haastatelluista journalisteista oli näistä menetelmistä tai niiden välittömistä vastakeinoista suoraa omakohtaista kokemusta.

\section{Lopuksi}

Tulosten perusteella voidaan todeta, että journalistit kohtaavat työssään erilaisia ja intensiteetiltään vaihtelevia ulkoisen vaikuttamisen menetelmiä myös Suomen kaltaisessa korkean sananvapauden länsimaassa. Ulkoinen vaikuttaminen on siis syytä tunnistaa tekijäksi, jolla voi potentiaalisesti olla suoria ja epäsuoria vaikutuksia journalismiin ja journalismin autonomiaan ja joka tulisi huomioida laajemmin aihetta tutkittaessa (ks. Reich \& Hanitzsch 2013, 133-134; Löfgren Nilsson \& Örnebring 2016, 889). Vaikuttamisen torjumiseen journalistit soveltavat sekä reaktiivisia että proaktiivisia vastakeinoja. Vastakeinojen tehokas hyödyntäminen kuitenkin edellyttää sitä, että koko journalistinen organisaatio ja komentoketju ovat vahvasti sitoutuneet professionalismiin ja journalismin autonomian ylläpitämiseen.

Tässä artikkelissa esittelemäni luokittelu ulkoisen vaikuttamisen menetelmistä ja vastakeinoista eroaa aikaisemmin mainitusta Luostarisen (1994) typologiasta kahdella keskeisellä tavalla. Ensinnäkin luokitteluni perustuu tutkimuskirjallisuuden sijaan 
empiriaan. Empiirisen aineiston käyttö kytkee luokitteluni määrättyyn ajalliseen ja maantieteelliseen kontekstiin, eli laajan yleistettävyyden sijaan pyrin täsmällisemmin kuvaamaan journalisteihin kohdistuvan ulkoisen vaikuttamisen kokonaisuutta nykyisessä hybridissä viestintäympäristössä ja korkean sananvapauden länsimaiden kontekstissa. Luokitteluni pyrkii siis myös tavoittamaan tällaiselle kontekstille tyypillisiä hienovaraisia vaikuttamisen menetelmiä ja mahdollistaa näin yksityiskohtaisemmat jatkoanalyysit ulkoisesta vaikuttamisesta tässä ympäristössä. Toiseksi, luokitteluni kuvaa journalistisen työn tekijöiden näkökulmaa ilmiöön ja siten painottaa luokitteluperusteena journalistien kokemuksia ja näkemyksiä esimerkiksi ulkoisten toimijoiden oletettujen intentioiden sijaan.

Haastatellut journalistit näkivät ulkoisen vaikuttamisen nykytilan kytkeytyvän moniin viestintäympäristön ja yhteiskunnan muutoksiin. Artikkelin lopuksi tarkastelenkin analyysini ja aikaisemman tutkimuksen pohjalta niitä laajempia taustatekijöitä ja kehityskulkuja, joihin ulkoinen vaikuttaminen tämänhetkisessä suomalaisessa mediaympäristössä yhdistyy. Olen tiivistänyt nämä neljäksi trendiksi: 1) journalismin omien resurssien heikkeneminen, 2) ammattimaisen viestintätoiminnan kasvu, 3) journalismin haasteet uusien taloudellisten ansaintamallien ja yleisöjen löytämisen kanssa sekä 4) yleisön suunnalta tulevan painostuksen ja uhan lisääntyminen.

Analysoidusta haastattelumateriaalista välittyi vahva huoli siitä, että ulkoista vaikuttamista suuremman rajoitteen journalismin autonomialle muodostaa tulevaisuudessa journalismin omien resurssien riittävyys kriittiseen ja tutkivaan työhön. Uhkana nähtiin sisältöjen monimuotoisuuden ja moniäänisyyden köyhtyminen ja journalismin typistyminen tiedotemateriaalin ja muiden tuottamien sisältöjen välittäjäksi (ks. myös Luostarinen 1994, 16). Jos journalismin itsenäisyys ja kriittinen potentiaali sekä näihin pohjautuva erityisasema heikentyvät, myös journalismiin kohdistuvalla ulkoisella vaikuttamisella saavutettavat edut vähenevät (emt.; Kunelius 2003, 23-25). Journalismin omien taloudellisten resurssien heikkenemisen on aikaisemmissa tutkimuksissa havaittu heikentäneen journalistien mahdollisuuksia itsenäiseen toimituksellisen työhön (Pöyhtäri ym. 2016, 9) ja lisänneen juttujen kierrättämistä sekä valmiin tiedotusmateriaalin käyttöä journalismissa (esim. Nikunen 2011; Juntunen 2011).

Vaikutuskeinoista puhuttaessa paljon yritysten ja viranomaisten kanssa tekemisissä olevat journalistit kuvasivat viestintätoiminnan kasvua ja ammattimaistumista Suomessa (vrt. Mykkänen ym. 2020; Kantola \& Lounasmeri 2014; Pöyhtäri ym. 2016, 10). Tietojen tarkkaan kontrollointiin perustuvien viestintäoppien nähtiin usein lyöneen läpi yritysmaailman lisäksi myös viranomaisviestinnässä, minkä toimittajat kokivat hankaloittavan journalismin mahdollisuuksia julkisen vallan tarkasteluun. Journalistien huolena oli, että yhä suurempi osa yhteiskunnallisesti merkittävästä vallankäytöstä pyritään saattamaan itsenäisen journalistisen valvonnan ulottumattomiin.

Erityisesti kaupallisille tiedotusvälineille työskentelevät journalistit nostivat usein esiin journalismin haasteet uusien ansaintamallien ja yleisöjen löytämisessä. Hybridissä viestintäympäristössä uudentyyppiset toimijat haastavat monelta suunnalta perinteisen journalismin asemaa ja tulonlähteitä (Chadwick 2017). Tilaajamäärien vähetessä haastateltavat pitivät uhkana sitä, että tiedotusvälineet tulevat tulevaisuudessa entistä 
riippuvaisemmiksi mainostuloista. Tämän he näkivät potentiaalisesti lisäävän mainostajien valtaa ja tekevän journalismista aiempaa haavoittuvampaa taloudellisten sanktioiden kautta tapahtuvalle vaikuttamiselle ja painostukselle, ellei koko journalistinen organisaatio ole vahvasti sitoutunut liiketoiminnan ja journalismin erottavan palomuurin ylläpitämiseen (vrt. Atal 2018).

Suurimpana muutoksena ulkoisessa vaikuttamisessa pidettiin yleisön ja keskenään samanmielisten toimijoiden muodostamien verkostojen harjoittaman häirinnän ja painostuksen yleistymistä. Tämän he näkivät eroavan niistä ulkoisen vaikuttamisen menetelmistä, joihin journalistit ovat tottuneet. Journalistit kokivat olevansa harjaantuneita esimerkiksi juttujen lähteiden ja kohteiden suunnasta tulevan ulkoisen vaikuttamisen suodattamiseen ja saavansa tähän poikkeustapauksia lukuun ottamatta hyvin tukea taustaorganisaatioiltaan. Näiden ulkoisen vaikuttamisen menetelmien torjuminen nähtiin vakiintuneena osana journalistisia rutiineja (vrt. Kuutti 1995, 245), ja haastateltavat kokivat professionalismin ja journalististen organisaatioiden sisäisen luottamuksen mahdollistavan tehokkaasti tällaisten menetelmien vaikutusten ehkäisemisen.

Verkon välityksellä organisoidut painostus- ja uhkailukampanjat koettiin puolestaan arvaamattomiksi ja hallitsemattomiksi, ja niiden nähtiin vaikuttavan ammattiroolin lisäksi uusilla tavoilla journalistien yksityiselämään. Journalistit olivat erityisen huolissaan laajamittaisen henkilöön kohdistuvan häirinnän yleistymisestä, jota yhteiskunnallisen ilmapiirin kiristymisen koettiin ruokkivan. Vaikka journalistiset organisaatiot saattoivat tarjota tukea myös näissä tapauksissa, niiden ei koettu pystyvän estämään tällaista toimintaa tai täysin torjumaan sen vaikutuksia yksittäiseen journalistiin.

Yleisön suunnasta tulevan painostuksen ja uhan epäsuorat ja välilliset seuraukset journalismille ja sen demokraattiselle roolille voivat muodostua merkittäviksi. Pelko häirinnästä ja painostuksesta voi johtaa itsesensuuriin ja vaikenemiseen, mikä muodostaa uhan ilmaisunvapaudelle ja journalismin toimimiselle yhteiskunnallisen tiedon välittäjänä (Pöyhtäri ym. 2013). Aikaisemman tutkimuksen perusteella tällä voi olla merkittäviä seurauksia journalismin sisällöille myös Pohjoismaiden kaltaisissa korkean sananvapauden yhteiskunnissa (ks. Hiltunen 2019; Hiltunen \& Suuronen 2020; Pöyhtäri ym. 2013; Löfgren Nilsson \& Örnebring 2016; Landsverk Hagen 2015). Useat journalistit nimesivätkin haastatteluissa aiheita, joita eivät mielellään käsittele tällaisten seurausten pelossa. Häirinnän ja uhkailun pelko voi myös ajaa journalisteja pois journalismin parista. Alanvaihdoksen tehnyt journalisti ilmoitti kokemustensa vaikuttaneen siihen, että hän hakeutui pois journalistiselta uralta. Osa muista haastatelluista ilmaisi harkinneensa vastaavaa.

Post ja Kepplinger (2019, 2437) ennustavat, että erilaisten vihamielisten yleisöreaktioiden kohtaamisesta muodostuu tulevaisuudessa entistä tavanomaisempi osa journalistin ammattia. Journalismin autonomian kannalta uudeksi merkittäväksi tekijäksi voikin muodostua se, miten yleisön suunnasta tulevan kuormituksen ja uhan vaikutusta journalisteihin pystytään vähentämään ja torjumaan. Ylipäätään journalismi vasta totuttelee toimimaan viestintäympäristössä, jossa sitä haastetaan yhteiskunnallisesti ja taloudellisesti uusilla tavoilla (Chadwick 2017) ja jossa yleisö odottaa siltä yhä useammin samanlaista julkista vastuuta ja läpinäkyvyyttä kuin muilta yhteiskunnallisilta 
vallankäyttäjiltä (Manninen 2019). Suomalaisen journalismin autonomian kannalta onkin keskeistä, miten näihin erisuuntaisiin paineisiin ja vaatimuksiin pystytään vastaamaan ja mukautumaan, ja millaiseen tärkeysjärjestykseen nämä tekijät asetetaan tiedotusvälineissä.

\section{Rahoitus}

Tätä tutkimusta ovat taloudellisesti tukeneet Media-alan tutkimussäätiö (apurahat 201710214 ja 20190120) sekä Suomen Akatemian rahoittama Communication Rights in the Age of Digital Disruption (CORDI) -tutkimuskonsortio.

\section{Kiitokset}

Kiitän tutkijatohtori Reeta Pöyhtäriä (Jyväskylän yliopisto) käsikirjoituksen kommentoinnista ja kehitysehdotuksista.

\section{Kirjallisuus}

Adams, Catherine (2018). "They go for gender first": The nature and effect of sexist abuse of female technology journalists. Journalism Practice 12:7, 850-869. https://doi.org/10.1080/17512786.2017.1350115

Ahva, Laura; van Dalen, Arjen; Hovden, Jan Fredrik; Kolbeins, Guðbjörg Hildur; Löfgren Nilsson, Monica; Skovsgaard, Morten \& Väliverronen, Jari. (2017). “A welfare state of mind?" Journalism Studies 18:5, 595-613. https://doi.org/10.1080/1461670X.2016.1249005

Aro, Jessikka (2019). Putinin trollit: tositarinoita Venäjän infosodan rintamilta. Helsinki: Johnny Kniga.

Atal, Maha (2018). The cultural and economic power of advertisers in the business press. Journalism 19:8, 1078-1095. https://doi.org/10.1177/1464884917725162

Bernard, Russel \& Ryan, Gery (1998). Text analysis: Qualitative and quantitative methods. Teoksessa: Bernard, Russel (toim.). Handbook of Methods in Cultural Anthropology. Walnut Creek: AltaMira, 595-645.

Binns, Amy (2017). Fair game? Journalists' experiences of online abuse. Journal of Applied Journalism Q Media Studies 6:2, 183-206. https://doi.org/10.1386/ajms.6.2.183_1

Chadwick, Andrew. (2017 [2013]). The Hybrid Media System: Politics and Power. Oxford: Oxford University Press. https://doi.org/10.1093/oso/9780190696726.001.0001

Chen, Gina Masullo; Pain, Paromita; Chen, Victoria; Mekelburg, Madlin; Springer, Nina \& Troger, Franziska (2018). You really have to have a thick skin: A cross-cultural perspective on how online harassment influences female journalists. Journalism 21:7, 877-895. https://doi.org/10.1177/1464884918768500

Clark, Marilyn \& Grech, Anna (2017). Journalists Under Pressure: Unwarranted Interference, Fear and Selfcensorship in Europe. Strasbourg: Council of Europe Publishing.

Eronen Jussi; Liski Jarno \& Vuorikoski Salla (2017). Ylegate. Helsinki: Barrikadi.

Finlex (2020). Yhdenvertaisuuslaki. Saatavilla: https://www.finlex.fi/fi/laki/alkup/2014/20141325 (luettu 13.8.2020).

Goyanes, Manuel \& Rodríguez-Castro, Marta (2018). Commercial pressures in Spanish newsrooms. Journalism Studies 20:8, 1088-1109. https://doi.org/10.1080/1461670X.2018.1487801

Guest, Greg; MacQueen, Kathleen \& Namey, Emily (2012). Applied Thematic Analysis. Los Angeles: Sage. https://doi.org/10.4135/9781483384436

Hemánus, Pertti (1983). Journalistinen vapaus. Helsinki: Gaudeamus.

Hiltunen, Ilmari (2019). Experiences of external interference among Finnish journalists: Prevalence, methods and implications. Nordicom Review 40:1, 3-21. https://doi.org/10.2478/nor-2018-0016

Hiltunen, Ilmari \& Suuronen, Aleksi (2020). Differences based on individual- and organizational-level factors in experiences of external interference among Finnish journalists. Journalism practice. https://doi.org/10.1080/17512786.2020.1815558 
Hiltunen, Ilmari \& Suuronen, Aleksi (2019a). Survey on External Interference Experienced by Finnish Journalists: Data Report. Tampere: Tampere University.

Hiltunen, Ilmari \& Suuronen, Aleksi (2019b). Kysely häirinnästä ja painostuksesta ohjelmatyötä tekeville yleläisille - raportti Yleisradion vaikuttamis- ja painostuskyselyn tuloksista. Helsinki: Yleisradio.

Hirsjärvi, Sirkka \& Hurme, Helena (1995). Teemahaastattelu. Helsinki: Yliopistopaino

JSN (2020). Journalistin ohjeet ja liite. Saatavilla: https://www.jsn.fi/journalistin_ohjeet/ (luettu 19.8.2020).

JSN (2017). Langettava 6398/YLE/16 ja 6401/YLE/16. Saatavilla: http://www.jsn.fi/sisalto/6398-yle-16-ja-6401-yle-16 (luettu 25.3.2020).

JSN (2016). Mitä neuvosto karsii ja miksi? Saatavilla: https://www.jsn.fi/blog/22-6-2016--mita-neuvosto-karsii-ja-miksi/ (luettu 18.8.2020).

Juntunen, Laura (2011). Leikkaa-liimaa-journalismia? Tutkimus uutismedian lähdekäytännöistä. Helsinki: Helsingin yliopisto.

Kantola, Anu \& Lounasmeri, Lotta (2014). Viestinnän ammattilaiset promootioyhteiskunnassa: aktivisteja ja ajatusjohtajia. Media Q viestintä 37:3, 3-21. https://doi.org/10.23983/mv.63041

Kluge, Susann (2000). Empirically grounded construction of types and typologies in qualitative social research. Forum Qualitative Social Research 1:1,14. Saatavilla: http://nbn-resolving.de/urn:nbn:de:0114-fqsooo1145 (luettu 12.3.2020).

Kodellas, Spyridon; Papastavrou, Niki; Giannakoulopoulos, Andreas \& Koutsompolis, Dimitris (2014). Journalists' victimization experiences and fear of crime at the workplace: Results of a questionnaire survey from Greece and Cyprus. European Journal of Communication 29:4, 480-494. https://doi.org/10.1177/0267323114531505

Koivunen, Anu (2017). \#Sipilägate and the break-up of the political bromance: Crisis in the relationship between Finnish media and politicians. Nordicom-Information 39:1, 44-51.

Kunelius, Risto; Noppari, Elina \& Reunanen, Esa (2010). Media vallan verkoissa. Tampere: Tampereen yliopisto.

Kunelius, Risto (2003). Viestinnän vallassa: johdatus joukkoviestinnän kysymyksiin. Helsinki: WSOY.

Kuutti, Heikki (toim.) (2011). Julkisuusjournalismi. Jyväskylä: Jyväskylän yliopisto.

Kuutti, Heikki (1995). Tutkiva journalismi - Journalistinen suuntaus ja suomalaisen journalismin tutkivuus. Jyväskylä: Atena.

Landsverk Hagen, Aina (2015). Meningers mot - netthat og ytringsfrihet i Norge. Oslo: Cappelen Damm Akademisk.

Lehtilä, Sannimari (2018). Valtakunnansyyttäjä ei nosta syytettä toimittaja Rebekka Härköseen kohdistuneista vihapuheista. Yle uutiset 13.3. Saatavilla: https://yle.fi/uutiset/3-10114003 (luettu 25.3.2020).

Lehtonen, Pauliina (2013). Itsensä markkinoijat - Nuorten journalistien urapolut ja yksilöllistyvä työelämä. Tampere: Tampere University Press.

Liski, Jarno (2020). Yhdeksän toimittajaa odotti yli vuoden ratkaisua siitä, loukkasiko paikkansa pitänyt kourimisuutisointi lahtelaisvaltuutetun kunniaa. Journalisti 27.4. Saatavilla: https://www.journalisti.fi/ajankohtaiset/yhdeksan-toimittajaa-odotti-yli-vuoden-ratkaisua-siitaloukkasiko-paikkaansa-pitanyt-kourimisuutisointi-lahtelaisvaltuutetun/ (luettu 17.8.2020).

Luostarinen, Heikki (1994). Mielen kersantit: julkisuuden hallinta ja journalistiset vastastrategiat sotilaallisissa konflikteissa. Helsinki: Hanki ja Jää.

Luque Martinez, Javier. (2015) Trolled by the State. British Journalism Review 26:4; 61-66. https://doi.org/10.1177/og56474815620728

Löfgren Nilsson, Monica \& Örnebring, Henrik (2016). Journalism under threat: Intimidation and harassment of Swedish journalists. Journalism Practice 10:7, 880-890. https://doi.org/10.1080/17512786.2016.1164614

Manninen, Ville (2019). Luottamus verkkojournalismia kohtaan perustuu harhakuviin. Media Q viestintä 42:4, 264-267. Saatavilla: https://journal.fi/mediaviestinta/article/view/88462 (luettu 2.4.2020)

Miller, Kaitlin \& Lewis, Seth (2020). Journalists, harassment, and emotional labor: The case of women in on-air roles at US local television stations. Journalism, February 2020.

https://doi.org/10.1177/1464884919899016

Mykkänen, Markus; Kuutti, Heikki \& Ikonen, Pasi (2020). Journalistit lobbaamisen kohteina: Tulokset. Jyväskylän yliopisto. Saatavilla: https://www.jyu.fi/hytk/fi/laitokset/kivi/tutkimus/hankkeet/medialobbaus/tulokset (luettu 13.8.2020). 
Mykkänen, Markus \& Ikonen, Pasi (2019). Media strategies in lobbying process: A literature review on publications in 2000-2018. Academicus: International Scientific Journal 20, 34-50. https://doi.org/10.7336/academicus.2019.20.03

Mäenpää, Olli (2017). Yleisradion journalistinen päätöksentekoprosessi - Arviointiraportti. Saatavilla: http://data.yle.fi/dokumentit/Uutiset/Arviointiraportti.pdf (luettu 4.2.2020).

Mäntylä, Jorma (2008). Journalistin etiikka. Helsinki: Gaudeamus.

Nikunen, Kaarina (2011). Enemmän vähemmällä: laman ja teknologisen murroksen vaikutukset suomalaisissa toimituksissa 2009-2010. Tampere: Tampereen yliopisto.

Oates, Jennifer (2015). Use of Skype in interviews: The Impact of the medium in a study of mental health nurses. Nurse Researcher 22:4, 13-17. https://doi.org/10.7748/nr.22.4.13.e1318

Obermaier, Magdalena; Hofbauer, Michaela \& Reinemann, Carsten (2018). Journalists as targets of hate speech: How German journalists perceive the consequences for themselves and how they cope with it. Studies in Communication and Media 7:4, 499-524. https://doi.org/10.5771/2192-4007-2018-4-499

Patton, Michael (1990). Qualitative Evaluation and Research Methods. Newbury Park: Sage.

Parker, Kelsey (2015). Aggression Against Journalists: Understanding Occupational Intimidation of Journalists Using Comparisons with Sexual Harassment. Tulsa: University of Tulsa.

Post, Senja \& Kepplinger, Hans Mathias (2019). Coping with audience hostility. How journalists' experiences of audience hostility influence their editorial decisions. Journalism Studies 20:16, 2422-2442. https://doi.org/10.1080/1461670X.2019.1599725

Pöyhtäri, Reeta; Väliverronen, Jari \& Ahva, Laura (2016). Suomalaisen journalistin itseymmärrys muutosten keskellä. Media Q viestintä 39:1, 1-23. https://doi.org/10.23983/mv.61434

Pöyhtäri, Reeta; Ahva, Laura \& Väliverronen, Jari (2014). Mistä on suomalainen toimittaja tehty? Worlds of Journalism -surveyn tuloksia Suomesta. Tampere: University of Tampere.

Pöyhtäri, Reeta; Haara, Paula \& Raittila, Pentti (2013). Vihapuhe sananvapautta kaventamassa. Tampere: Tampere University Press

Reich, Zvi \& Hanitzsch, Thomas (2013). Determinants of journalists' professional autonomy: Individual and national level factors matter more than organizational ones. Mass Communication and Society 16:1, 133-156. https://doi.org/10.1080/15205436.2012.669002

Reunanen, Esa \& Koljonen, Kari (2014). Toimittajan sanansijat. Tampere: Tampere University Press.

Revers, Matthias (2017). Contemporary Journalism in the US and Germany. New York: Palgrave Macmillan. https://doi.org/10.1057/978-1-137-51537-7

Rinne, Jarmo (2011). Henkilökohtaistuva politiikka: Tutkimusmatkoja refleksiiviseen kansalaistoimintaan. Tampere: Tampere University Press.

Ross, Karen \& de Bruin, Marjan (2004). Gender and Newsroom Cultures: Identities at Work. Cresskill, NJ: Hampton Press.

RSF (2019). 2019 RSF Index: Has a Dam Burst in Europe? Saatavilla: https://rsf.org/en/2019-rsf-index-has-dam-burst-europe (luettu 8.4.2020).

Saldaña, Johnny (2013). The Coding Manual for Qualitative Researchers. Los Angeles: Sage.

Urbániková, Marína (2019). Journalistic autonomy in peril? A case study of the newsroom conflict in publicservice radio and television of Slovakia (RTVS). Konferenssipaperi: "Media control as source of political power in Central and Eastern Europe", Helsinki, 02-03 syyskuuta 2019.

Waisbord, Silvio (2013). Reinventing Professionalism - Journalism and News in Global Perspective. Cambridge: Polity. 
Liite 1.

Teemahaastattelurunko: Suomalaisiin journalisteihin kohdistuva ulkoinen vaikuttaminen

1. Oma tausta - Koulutus ja työura

1.1. Ikä ja sukupuoli?

1.2. Millainen on ammatillinen taustasi? Miten päädyit toimittajaksi?

1.3. Millainen koulutus sinulla on?

1.4. Kuinka kauan olet tehnyt journalistista työtä?

1.5. Missä tiedotusvälineissä olet aiemmin ollut töissä?

1.6. Missä työskentelet tällä hetkellä? Millaisessa työsuhteessa ja missä tehtävissä? Miten kuvailisit tätä tiedotusvälinettä?

1.7. Mistä aiheista teet eniten juttuja? Oletko erikoistunut johonkin aihepiiriin?

1.8. Miten kuvailisit itseäsi toimittajana? (esimerkiksi arvot, pyrkimykset, ammatti-identiteetti)

\section{Kokemukset ulkoisesta vaikuttamisesta}

2.1. Miten sinun tämänhetkiseen journalistiseen työhösi pyritään useimmin vaikuttamaan ulkopuolelta? Voitko antaa tästä esimerkkejä?

2.2. Miten tämä näkyy työssäsi? Millaisten aiheiden ja tapausten yhteydessä ulkoista vaikuttamista esiintyy?

2.3. Millaisista ulkoista vaikuttamista olet kohdannut aikaisemmin työurallasi?

2.4. Onko ulkoisella vaikuttamisella ollut konkreettista vaikutusta toimintaasi journalistina tai tekemääsi journalismiin? Millaista? Onko ulkoisella vaikuttamisella seurauksia työsi kuormittavuuteen?

2.5. Onko sinuun kohdistuvassa ulkoisessa vaikuttamisessa tapahtunut muutoksia? Ovatko esimerkiksi sen määrä tai keinot muuttuneet jollakin tavalla työurasi aikana? Mistä arvelet tämän johtuvan?

2.6. Missä menee mielestäsi raja erittäin kriittisen palautteen ja ulkoisen vaikuttamisen välillä? Millaista käsittelyä toimittajan tulee mielestäsi kestää? Mikä on hyväksyttävää ja mikä ei?

2.7. Onko työhösi pyritty vaikuttamaan haastattelutilannetta tai tiedonsaantia ohjaamalla tai rajoittamalla? Millaisissa tilanteissa?

2.8. Miten menettelet haastateltavan pyytäessä lausuntojensa ennakkotarkastusta? Onko tämä johtanut vaikuttamisyrityksiin?

2.9. Miten suhtaudut pyyntöihin muuttaa tai poistaa jutusta jotain ennen julkaisua? Mihin perustat harkintasi näissä tilanteissa? Teetkö poikkeuksia?

\section{Ulkoisen vaikuttamisen käsittely omassa työssä ja työyhteisössä}

3.1. Onko ulkoista vaikuttamista käsitelty omassa työyhteisössäsi?

3.1.1. Kollegoiden kanssa?

3.1.2. Esihenkilöidesi kanssa?

3.1.3. Onko sinulla esimerkkitapauksia aiheen käsittelystä työyhteisön sisällä

3.2. Miten ulkoista vaikuttamista pyritään torjumaan työyhteisössäsi? Onko tätä suunniteltu tietoisesti? Onko tästä olemassa virallista ohjeistusta tai linjauksia?

3.3. Luotatko esihenkilöidesi tai välineesi omistajien kykyyn torjua ulkoista vaikuttamista? Onko sinulla esimerkkejä tilanteista, joissa on mielestäsi toimittu hyvin tai huonosti?

3.4. Miten hyvin välineessäsi toteutuu mielestäsi se, että toimituksellista sisältöä koskevat päätökset tehdään journalistisin perustein eikä päätösvaltaa luovuteta ulkopuolelle missään tilanteessa?

3.5. Millaisin keinoin välineesi kykyä torjua ulkoista vaikuttamista voitaisiin mielestäsi parantaa?

\section{Näkemykset ulkoisesta vaikuttamisesta}

4.1. Miten arvioisit yleensä suomalaisen journalismin kykyä torjua ulkoista vaikuttamista? Pystyvätkö seuraavat vaikuttamaan journalismin sisältöihin?

4.1.1. Poliitikot

4.1.2. Mainostajat tai yritykset

4.1.3. Intressiryhmät

4.1.4. Yleisö tai muut ulkopuoliset

4.2. Tulisiko ulkoista vaikuttamista tuoda julki? Jos pitäisi, niin miten ja mitä kanavia pitkin? Milloin yleisöllä on oikeus tietää pyrkimyksistä ulkoiseen vaikuttamiseen?

4.3. Oletko itse kehittänyt menetelmiä tai periaatteita ulkoisen vaikuttamisen torjumiseksi? Millaisia?

4.4. Miten journalistien itsenäisyyttä ja riippumattomuutta voitaisiin yleisesti edistää Suomessa? Millaisiin asioihin tulisi kiinnittää huomiota?

4.5. Onko journalisteihin kohdistuva ulkoinen vaikuttaminen mielestäsi yleistynyt tai muuttunut jollakin tavalla? Mistä uskot tämän johtuvan?

4.6. Oletko huolissasi toimittajiin kohdistuvasta vaikuttamisesta? Miksi tai miksi et?

4.7. Onko sinulla aihepiiristä kokemuksia, näkemyksiä tai ajatuksia, joita ei käsitelty aikaisemmin tässä haastattelussa ja jotka pitäisi tuoda siinä julki? 